\title{
Price Rigidity and Price Dispersion: \\ EVIDENCE FROM MICRO DATA
}

\author{
by
}

Eyal Baharad and Benjamin Eden

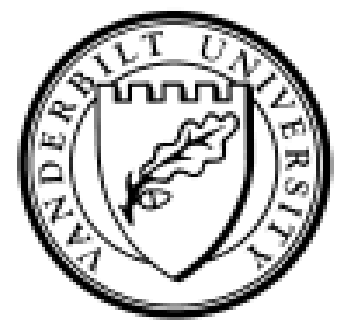

Working Paper No. 03-W21

September 2003

\section{DEPARTMENT OF ECONOMICS \\ VANDERBILT UNIVERSITY \\ NASHVILLE, TN 37235}

www.vanderbilt.edu/econ 
PRICE RIGIDITY AND PRICE DISPERSION: EVIDENCE FROM MICRO DATA*

Eyal Baharad

The University of Haifa

Benjamin Eden

Vanderbilt University and The University of Haifa.

August 2003

We use large unpublished data set about the prices by store of 381 products collected by the Israeli bureau of statistics during 1991-92 in the process of computing the CPI. On average $24 \%$ of the stores changed their price where the average is over products and months. Using the standard calculation this would imply that on average prices remain unchanged for 4.1 months. We argue that the standard calculation suffers from a large aggregation bias due to Jensen's inequality and our best estimate suggests that prices remain unchanged on average for more than 7.5 months. We then assess the importance of price rigidity in generating price dispersion. We find no evidence that price rigidity as measured by the frequency of nominal price changes is related to price dispersion. We also find no evidence that a shock to the inflation rate increases price dispersion. These findings are not consistent with standard versions of the staggered price setting model but are roughly consistent with a simple version of the uncertain and sequential trade model.

* This paper benefited from comments provided by the participants of the workshop at the Chicago Fed and by comments provided by Jeff Campbell. 


\section{INTRODUCTION}

There is a growing literature that attempts to use micro data for assesing the importance of price rigidity. Some examples are: Carlton (1986), Cecchetti (1986), Lach and Tsiddon (1992), Kashyap (1995), Eden (2001), Bils and Klenow (2002) and Crucini and Shintani (2002). The estimation of the length of the period for which prices remain unchanged is a main concern of this literature. Taylor (1999) summarized the literature by saying that on average prices remain unchanged for about a year. Bils and Klenow (2002, hereafter BK) use unpublished US data from the BLS for 1995 - 1997 on the monthly frequency of price changes for 350 detailed categories of consumer goods and services. They find that the median duration is less than 5 months and the mean duration is less than 4 months.

Here we use Israeli data about the prices of 381 narrowly defined products by stores which were collected by the Israeli bureau of statistics in the process of computing the CPI during the period 19911992. We show that the BK estimates may suffer from a downward aggregation bias. This bias arises because of Jensen's inequality and correcting it may significantly narrow the difference between the estimates cited by Taylor (1999) and the new estimates obtained by BK. Using the BK estimation method we obtain very similar estimates of the average length of the period (4.1 months) but after correcting for the aggregation bias we obtain an estimate of 7.5 months which may still be downwardly biased. 
We then turn to asses the economic importance of price rigidities by testing the predictions of two types of models. The staggered price setting model proposed by Taylor (1980) and more recently studied by Chari, Kehoe and McGrattan (2000, 2001) and the uncertain and sequential trade (UST) models of the type studied by Eden (1990, 1994), Lucas and Woodford (1994), Williamson (1996), Woodford (1996) and Bental and Eden $(1996,2002)$

In the simple version of the staggered price setting model a fraction $1 / \mathrm{N}$ of the firms change their nominal price every period and each firm changes its nominal price every $N$ periods. In this model prices are rigid in the sense that sellers would choose to change their nominal price during the $\mathrm{N}$ periods in which the price is fixed if they could costlessly do it.

In a simple version of the UST model there is price dispersion and sellers' price target is a range rather than a point. Within the equilibrium range, sellers are indifferent between quoting a relatively high price and quoting a low price because the low price implies a higher probability of making a sale. In these models a seller may not change his nominal price when inflation erodes his real price even if he could costlessly do so.

The observation that sellers change their nominal prices in unsynchronized jumps is consistent with both the staggered price setting model and the UST model. But the policy implications of the two models are very different. The staggered price setting model tends to support policies that are designed to improve the working of the market. The sequential trading model tends to support neo-classical policies. It is therefore important to see if prices are really rigid as in the 
staggered price setting model or seemingly rigid as in the sequential trade model. Here we attempt to distinguish between the two models by the behavior of relative price variability.

In the staggered price setting model, deviations from the law of one price occurs because of price rigidity. (If all stores were allowed to change their nominal price every month they will always quote the same price.) We may therefore expect that products which change their prices less often will exhibit more relative price variability. The staggered price setting model has also a strong prediction about the response of relative price variability to a shock that leads to a change in the desired nominal price. To build some intuition we start from an equilibrium in which all sellers post the same price. We then hit the system with a shock. Since only a fraction $1 / \mathrm{N}$ of the sellers can change their price immediately after the shock, the shock will create a price difference between sellers who could change their nominal price to sellers who could not. The standard deviation of prices will gradually go back to zero as all sellers adjust their prices and the economy reaches the new steady state equilibrium.

In the UST model prices are flexible and therefore the economy will reach the new equilibrium immediately after the shock. If the shock is monetary there may be no effect on relative price variability. If the shock is real there may be a permanent effect on relative price variability and the full effect of the shock is realized immediately after the shock.

We find that (a) products that change their prices less often do not exhibit more relative price variability and (b) a shock to prices does not have a positive effect on relative price variability. These 
findings are not consistent with the predictions of the simple version of the staggered price setting model but are consistent with the UST model.

2. DATA

We use monthly data collected by Israel's Central Bureau of Statistics as inputs for computing the CPI. These are prices actually quoted to the surveyor when visiting the store (not scanner data). We use mainly the 1991-1992 sample described in Eden (2001). For the sake of comparison we also use in some of the analysis, the Lach and Tsiddon (1992) earlier samples from 1978-79 and 1981-82. The average monthly inflation rate was $4.3 \%$ in $1978-79,6.3 \%$ in $1981-82$ and $0.8 \%$ in 1991-92. The data from 1991-92 contain 115,394 monthly observations of prices by stores and products, collected from 458 stores which sold 390 different products over 24 months. We eliminated all products and stores with incomplete information. This led to a sample of 62,629 observations about the price changes of 381 products for 23 months. The number of stores per product is 7 on average. For some of the analysis we use only 371 products for which there are direct observations about the length of the period between two consecutive nominal price changes.

The distribution of products by the fraction of stores which changed their nominal prices in an average month is in Figure 1. This distribution is similar to the distribution in Figure 1 of Bills and Klenow (2001, hereafter BK) who study a US sample of 350 product categories. Their reported statistics are almost identical to the statistics reported in Figure 1. 


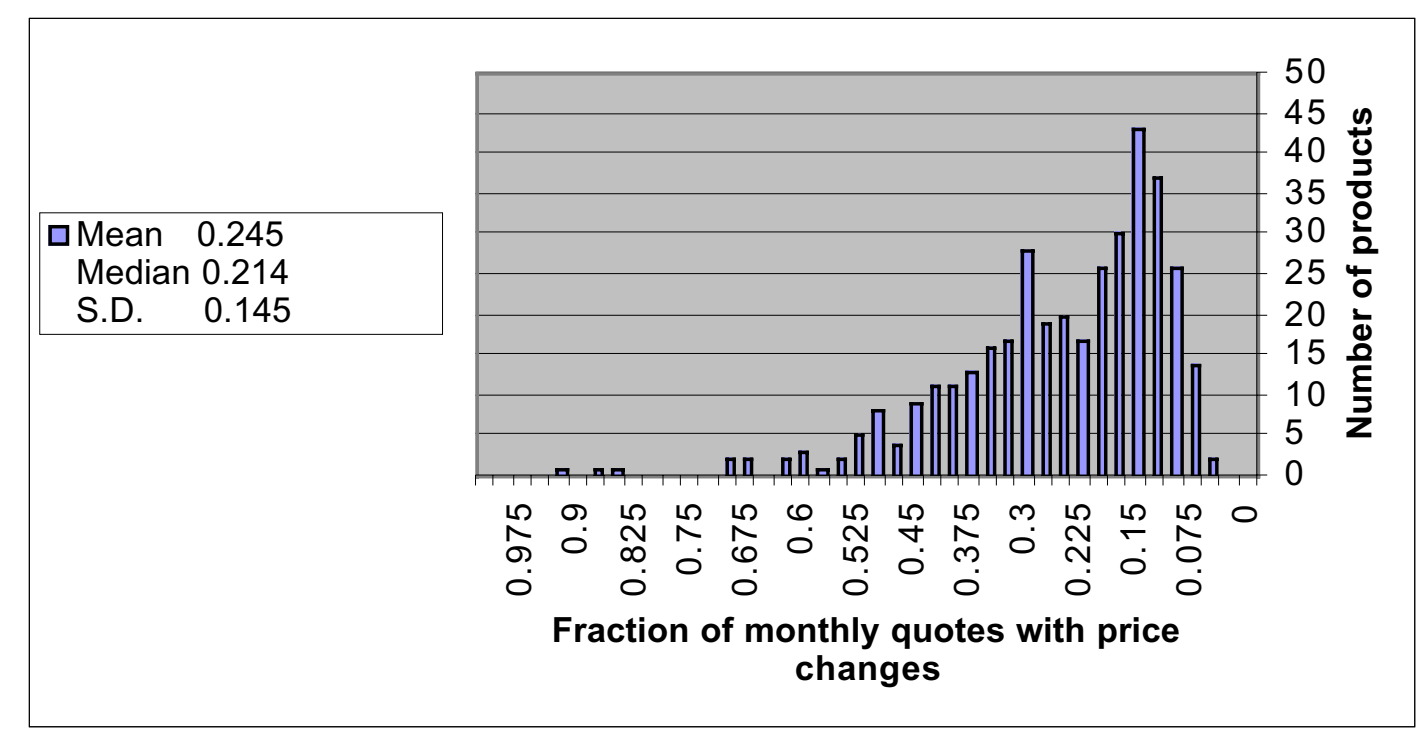

Figure 1: The distribution of 371 products by the average (per month) fraction of stores that changed their nominal price.

For the median product the length of the period between two consecutive nominal price changes (the length of the period for short) is often calculated by $1 / 0.21=4.7$ months. The average length of the period is often calculated by $1 / 0.24=4.1$ months. We now argue that these calculations may be downward biased.

Aggregation bias: Let $\mathrm{x}_{\text {it }}$ denote the fraction of stores that changed the price of product $i$ in month $t$ and let $E_{i t}\left(x_{i t}\right)$ denote the average fraction over products (i) and time (t). Since Jensen's inequality implies $E_{i t}\left(1 / x_{i t}\right) \geq 1 / E_{i t}\left(x_{i t}\right)$, the average length of the period per store is underestimated if we use $1 / E_{i t}\left(x_{i t}\right)$ instead of $E_{i t}\left(1 / x_{i t}\right)$. To examine whether the aggregation over products bias is large we computed in Table 1 the average (over time) fraction for each product 
$E_{t}\left(x_{i t}\right)$. We use $1 / E_{t}\left(x_{i t}\right)$ as an estimate for the length of the period for product $i$ and average over products to get: $E_{i}\left(1 / E_{t}\left(x_{i t}\right)\right)=5.7$ months. If we use the average fraction $E_{i t}\left(x_{i t}\right)=0.245$ to compute the length of the product we get: $1 / 0.245=4.1$ which is about $30 \%$ less than 5.7 .

A similar problem arises when we aggregate over time. To illustrate, we assume two stores selling the same product. One store changes its price every month; the other every two months. We will observe $\mathrm{x}=1,1 / 2,1,1 / 2 \ldots$ and on average $\mathrm{Ex}=3 / 4$. The average length of the period estimated by $1 / \mathrm{Ex}$ is: $4 / 3$. But the true average is: 1.5 . This can be obtained by calculating $1 / x$ first $(1 / x=1,2,1,2 \ldots)$ and then taking the average.

To estimate the bias due to time aggregation we computed $E_{t}\left(1 / x_{i t}\right)$ for products with strictly positive $x_{i t}$ for all $t$. There were 54 products for which this statistic could be computed. The average length of the period for these products was $E_{i t}\left(1 / x_{i t}\right)=3.48$. If we first compute the average frequency per product $E_{t}\left(x_{i t}\right)$ and then take the average over products we get: $E_{i}\left(1 / E_{t}\left(x_{i t}\right)\right)=2.66$. The bias due to time aggregation is thus also about $30 \%$

Assuming that time aggregation leads to a $30 \%$ bias in all the products we may correct for the time aggregation bias. This leads to (5.7) $(1.3)=7.5$ months which is $80 \%$ higher than the estimate of 4.1 obtained as 1 over $E_{i t}\left(x_{i t}\right)$. The estimate of 7.5 months may still be downward biased if the length of the period varies within stores. 
We also have 13770 direct observations about the length of the period between two consecutive nominal price changes, $\Delta$. $^{1}$ The (unweighted) average and the standard deviation of $\Delta t$ are reported in Table 1 for each product. Products with higher mean of $\Delta$ t tends to have higher standard deviation measured across stores (the correlation between the standard deviation and the mean is 0.78).

The average $\Delta t$ per price is 5.26 months. The average of $\Delta t$ per spell is 2.7 months. The first is computed by taking a weighted average of $\Delta t$ where the weights are the observations $\Delta$ t themselves. The second is an unweighted average. To understand the difference between the two it may be useful to go back to our two stores example: One changes its price every month and the other every two months. The average duration per price is 1.5 months. But if we have a sample of 100 observations we will get 100 spells of one month and 50 spells of 2 months. The unweighted average is $200 / 150=4 / 3$. This is the average per spell which is less than the average per price. The average per price can be computed by computing a weighted average that gives the 2 months spells

1 The observations about $\Delta$ t are obtained in the following way. For each price change observation we have a code for the product, a code for the store and a time index which goes from 1 to 23 . We sort the data by product and then by store and then by time index. After doing it we can read the price changes of a given product in a given store in all the 23 months for which we have observations. We then eliminated observations with no change in nominal price (dp $=0)$. After doing it, the lag time index observation is the last time that a nominal price change was made. We compute $\Delta t$ as the difference between the current and the lag time index. 
a weight of 2 and the one month spells a weight of 1 . This leads to $[100(1)+50(2)(2)] / 200=3 / 2 \cdot \cdot^{2}$

The direct measure of $\Delta t$ suffers from a selection (censoring)

bias because long time periods are more likely not to be in our sample.

(For example, a 24 months time period will not make our 23 months sample). To get a sense of how serious is the bias we computed the weighted average for all observations of $\Delta$ t in the first 19 months. This yields a weighted average of 4.66 which is $11 \%$ less than the 5.26 estimate that we get for 24 months.

We now turn to use the direct measure $\Delta$ t to examine some hypotheses about the length of the period.

What determines $\underline{\underline{t}} \underline{\underline{ }}$

Bills and Klenow (2001) explain variations in the length of the period by product characteristics. They find that variables that capture volatility of market supply and demand are the robust factors in explaining a good's frequency of price change.

Here we ask whether it is the product or the store characteristics that matter. To examine this question we use the prediction of sticky price models about the relationship between $\Delta t$ and the size of the "jump" in the nominal price $(\Delta \mathrm{p})$ :

$$
\Delta \mathrm{p}=\pi \Delta \mathrm{t}
$$

2 We thanks Jeff Campbell for the distinction between the average per price and the average per spell. 
where $\pi$ denotes the relevant inflation rate. Equation (1) says that the nominal price jump covers the real price erosion, $\pi \Delta t$, due to inflation which occurred since the last nominal price change.

The relationship (1) requires the assumption that firms change their nominal prices to meet a price target. For example, in Dotsey, King and Wolman (1999) firms follow a state dependent strategy. In their model the fixed cost of changing nominal price is an i.i.d random variable. After drawing the fixed cost the firm decides whether or not it wants to change its nominal price to the target price which is common to all firms. The length of the period in this model may vary across stores and products but firms that did not adjust their nominal price for a relatively long time will make a relatively large nominal price change.

In the time dependent model suggested by Calvo (1983) the store gets an opportunity to adjust its nominal price at random and exogenous time intervals. Also in this case, the target price is common to all firms that get the opportunity to make a price change and therefore (1) holds.

In the UST model the price target is a range rather than a point. Therefore the UST alternative does not lead to (1). Eden (2001) finds no support for (1) even after allowing for product and store specific inflation rates.

We may expect however that (1) should hold in some average sense. Assuming no trend in relative prices a store that increases its price by large jumps on average must do it relatively rarely because otherwise it will become more expensive over time. The same argument applies for 
products. We therefore use the average of $\Delta \mathrm{p}$ computed for the product as a proxy for the product characteristics and the average of $\Delta \mathrm{p}$ computed for the store as a proxy for the store characteristics. We ran an OLS regression of $\Delta t$ on the current nominal price change $(\Delta p)$, the average of $\Delta \mathrm{p}$ for the product, the average of $\Delta \mathrm{p}$ for the store, a constant and monthly dummies. The regression results are reported in Table 2 (first line). This regression suggests that both store and product characteristics are important for predicting the length of the period but $\Delta \mathrm{p}$ is not important. Because of a possible selection problem we split the sample and ran this regression for products with high and low frequencies of price change. The results were very similar.

We also computed the correlation between $\Delta t$ and two averages of $\Delta$ t. The correlation of $\Delta t$ with the average of $\Delta t$ for the store is 0.46 . The correlation of $\Delta t$ with the average of $\Delta t$ for the product is 0.51 . This together with the above regression suggests that the store characteristics are as important as the product characteristics.

\section{$\underline{\text { Price rigidity and steady state relative price variability: }}$}

The staggered price setting model attributes the departure from the law of one price to price rigidities. This suggests a positive relationship between the steady state relative price variability and price rigidity. We now illustrate this proposition for a deterministic steady state.

We assume that the typical store changes its nominal price every $\mathrm{N}$ periods by $N \pi$ percent so that the rate of inflation is $\pi$ percent per period. The distribution of the log of prices at time $t$ is uniform: 


$$
\operatorname{lnp}_{t}=\{i \pi \text { with probability } 1 / \mathrm{N} \text { where } i=1,2, \ldots, N\} \text {. }
$$

At time $t+1$ the stores that quotes the lowest price will change it by $N \pi$ percent to $(\mathrm{N}+1) \pi$ and as a result the price distribution will change to:

$$
\operatorname{lnp}_{t+1}=\{i \pi \text { with probability } 1 / \mathrm{N} \text { where } i=2, \ldots, N+1\} .
$$

The range of the price distribution does not change over time and is given by: (N - 1) $\pi$. Since the log price distribution is uniform the variance of $\operatorname{lnp}$ is $\pi^{2}\left(\mathrm{~N}^{2}-1\right) / 12$. It follows that:

Claim 1: The steady state standard deviation of lnp increases with the rate of inflation $\pi$ and the length of the contract $N$.

Eden (2001) examined the first prediction about the relationship between $\pi$ and the variance of $\operatorname{lnp}$ and rejected it. ${ }^{3}$ To test the second prediction we computed the standard deviation $\mathrm{SD}\left(\mathrm{InP}_{\text {it }}\right)$ for each product $i$ and month $t$ (across stores) and correlated it with a measure of the length of the period for this month and product $1 / x_{i t}$. This correlation was computed for 381 products for all months with strictly positive $x_{i t}$. The correlation coefficient is -0.02 .

3 This is different from the so called stylized fact because most of the literature uses the standard deviation of nominal price changes (dp) which is not a good proxy for the standard deviation of lnp. 
We also computed the correlations between the average standard deviation $E_{t}\left[S D\left(\ln P_{i t}\right)\right]$ and the average per product measures of price rigidity in Table 1 . These correlations are tiny. They are: -0.13 with the average frequency $E_{t}\left(x_{i t}\right), 0.05$ with the average direct observation of the length of the period $\Delta t_{i}, 0.03$ with $1 / E_{t}\left(x_{i t}\right)$ and 0.11 with $E_{t}\left(1 / x_{i t}\right)$. These correlations are based on $381,371,381$ and 54 observations (products) respectively.

Finally, we ran the direct observation of the length of the period, $\Delta t$, on the average standard deviation for the product, $E_{t}[S D(\operatorname{lnP} i t)]$, and the product specific inflation rate. The results are reported in Table 2. According to Claim 1 the coefficient of $E_{t}\left[S D\left(\ln P_{i t}\right)\right]$ should be positive and the coefficient of $\pi$ should be negative. The regression results suggest no clear relationship between the length of the period, the rate of inflation and price dispersion.

The UST model is silent about the steady state relationship between price dispersion and the average length of the period. The two models have however different predictions about the responses to shocks. We now turn to exploint this difference.

\section{THEORETICAL IMPULSE RESPONSE ANALYSIS}

What happens to price dispersion after a shock that leads to a change in prices? To build some intuition, we start from a steady state equilibrium in which all sellers post the same price. The industry then experiences a change in demand and supply conditions and as a result sellers want to change their price. After the shock only a fraction $1 / \mathrm{N}$ of the sellers can change their price and therefore there is a price 
difference between sellers who could change their nominal prices to sellers who could not. Thus a shock that leads to a change in prices has an effect on price dispersion. This conclusion does not depend on the source of the shock (it can be monetary or real) or whether the shock is transitory or permanent in nature.

For the sake of concreteness, we assume that at the initial steady state all sellers post the price of 1 and immediately after the change a fraction $1 / \mathrm{N}$ of the sellers change their price by $\Delta$ percent. The rate of inflation immediately after the change is the weighted average:

$\mathrm{DP}_{t}=\Delta(1 / \mathrm{N})+0[(\mathrm{~N}-1) / \mathrm{N}]=\Delta / \mathrm{N}$

The variance of the $\log$ of prices is ${ }^{4}$

$\operatorname{VAR}_{t}=(\mathrm{DP})^{2}+\Delta^{2}[1-(2 / \mathrm{N})](1 / \mathrm{N})$

It follows that when $\mathrm{N} \geq 2$,

Claim 2: A shock that affect the rate of inflation at time $t$ ( $\left.\mathrm{DP}_{t}\right)$ also affect the standard deviation of the log of prices at time $t\left(S D_{t}\right)$. The effect on the standard deviation is larger: $\mathrm{SD}_{t}>\mathrm{DP}_{t}$.

4 The derivation is as follows. A fraction $1 / \mathrm{N}$ post $\mathrm{P}$. A fraction $(\mathrm{N}-1) / \mathrm{N}$ post $1 . \Delta=\operatorname{lnP}$. The average of the log of prices is: $(1 / N) \ln P=\Delta / N$. The variance of the log of prices is:

$\operatorname{VAR}_{\mathrm{t}}=(\Delta / \mathrm{N})^{2}[(\mathrm{~N}-1) / \mathrm{N}]+(\Delta-\Delta / \mathrm{N})^{2}(1 / \mathrm{N})$

$=(\mathrm{DP})^{2}[(\mathrm{~N}-1) / \mathrm{N}]+(\Delta-\mathrm{DP})^{2}(1 / \mathrm{N})$

$=(\mathrm{DP})^{2}[(\mathrm{~N}-1) / \mathrm{N}]+\left[\Delta^{2}-2 \Delta \mathrm{DP}+(\mathrm{DP})^{2}\right](1 / \mathrm{N})$

$=(\mathrm{DP})^{2}+\left(\Delta^{2}-2 \Delta \mathrm{DP}\right)(1 / \mathrm{N})$

$=(\mathrm{DP})^{2}+\Delta^{2}(1-2 / \mathrm{N})(1 / \mathrm{N})$. 
This claim derives the impact effect of a shock. We expect that after the initial impact both DP and SD will gradually go back to the baseline. Figure 2 illustrates this possibility by plotting a theoretical impulse response functions to a shock of DP in a vector auto regression (VAR) with two variables: DP and SD.

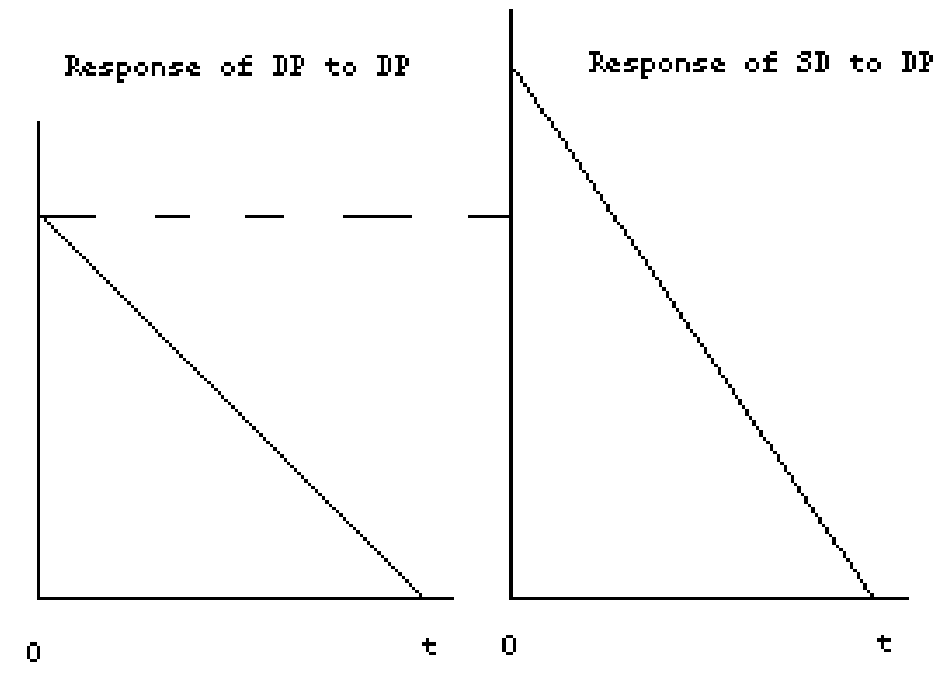

Figure 2: Possible responses to a DP shock under the staggered price setting model.

We now generalize Claim 2 to the case of a deterministic steady state with non-zero inflation rate and then to the case of a stochastic steady state.

A deterministic steady state with strictly positive inflation rate: We now start from a steady state with a positive inflation rate of $\pi$ per period. At time $t$ the economy experiences a shock that disturbs the initial steady state equilibrium. After experiencing the shock firms 
that change their price at time $t$ change it by $\mathrm{N}(\pi+\Delta)$ percent instead of just by $N \pi$ percent. The distribution of lnpt is now:

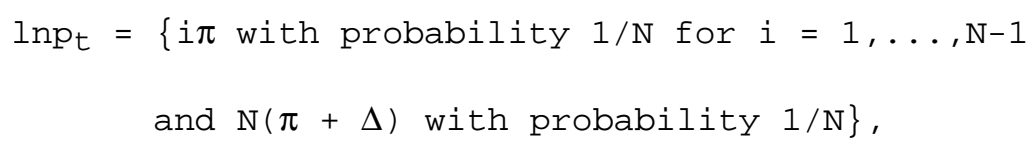

instead of (2). Using $\operatorname{Var}(\mathrm{x})=\mathrm{Ex}^{2}-(\mathrm{Ex})^{2}$ to compute the variance of (4) we get:

$$
\begin{gathered}
\operatorname{Var}(\operatorname{lnp} t)=(1 / N)\left[\pi^{2} \Sigma_{i=1}^{N-1} i^{2}+(\pi+\Delta)^{2} N^{2}\right]-[\pi N / 2+(\pi+\Delta)]^{2} \\
=C+\Delta(N-2) \pi+\Delta^{2}(N-1) .
\end{gathered}
$$

where $C=(1 / N) \pi^{2} \Sigma_{i=1}^{N-1} i^{2}-(\pi N / 2)^{2}-\pi^{2}$. Since $N \geq 2$, also in this case a shock to the inflation rate increases relative price variability and the increase in the standard deviation is larger than the shock to the inflation rate $\Delta$. We can therefore generalize claim 2 to the case in which the initial steady state inflation rate is positive.

Starting from a stochastic steady state equilibrium: We now assume that the rate of inflation flucuates in a stochastic manner in the positive range. When the realization of $\mathrm{lnp}$ for stores that changed their prices at time $t-i$ is $z_{t-i}$ the expected log price of the stores that change their nominal price at time $t$ is $z_{t}$. Since the inflation rate is always positive we assume: $z_{t}>z_{t-1}>\ldots>z_{t+1-N}$. In the absence of a shock the distribution of log prices is: 


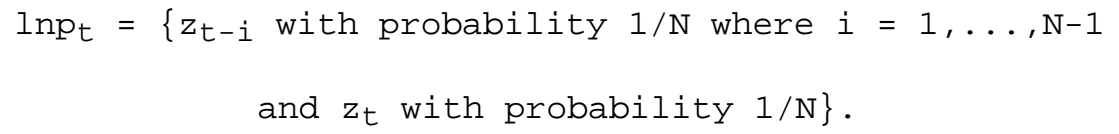

We consider now a shock at time $t$. As a result of the shock the stores that change their price at time $t$ change it to $z_{t}+\varepsilon$ instead of $z_{t}$. The distribution of lnpt after the shock is:

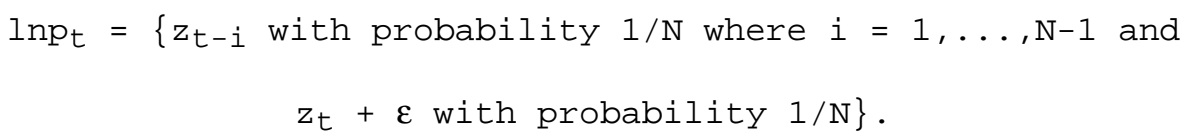

The variance of lnp after the shock is:

$$
\begin{gathered}
\operatorname{Var}(\operatorname{lnp})=(1 / N) \Sigma_{i=1}^{N-1}\left(z_{t-i}\right)^{2}+(1 / N)\left(z_{t}+\varepsilon\right)^{2} \\
\quad-\left[(1 / N) \Sigma_{i=1}^{N-1} z_{t-i}+(1 / N)\left(z_{t}+\varepsilon\right)\right]^{2} \\
=C+(2 / N)\left(z_{t}-A\right) \varepsilon+(1 / N)[1-(1 / N)] \varepsilon^{2},
\end{gathered}
$$

where $A=(1 / N) \Sigma_{i=1}^{N} z_{t-i}, a=(1 / N) \Sigma_{i=1}^{N-1} z_{t-i}$ and

$C=(1 / N)\left(z_{t}\right)^{2}-a^{2}-2 a(1 / N) z_{t}-(1 / N)^{2}\left(z_{t}\right)^{2}$. Since $z_{t}>z_{t-i}, z_{t} \geq A$ and the coefficient of $\varepsilon$ is positive. Since $N \geq 2$, the coefficient of $\varepsilon^{2}$ is also positive. Therefore, a positive shock to the inflation rate increases relative price variability. Thus we can generalize the first part of Claim 2 to the case in which the rate of inflation fluctuates over time. 
The UST alternative: Unlike the staggered price setting model, the effect of a shock to prices in the UST model depends on the nature of the shock. A purely monetary shock to the rate of inflation will have no effect on price dispersion while a real shock may affect price dispersion.

We start with the case of a pure monetary shock in Eden (1994). Money follows a random walk (the rate of change in the money supply is i.i.d). There is uncertainty about the amount of transfer payment that buyers will receive during trade and about the nominal amount that they will spend. The transfer process is like rain: Everyone observes the amount of transfers (helicopter money) as they occur but no one knows when it will stop. It is assumed that money arrives in batches and each batch of dollars that arrives opens a new Walrasian market. There are thus many potential markets that open sequentially and sellers allocate their output across one or more of these potential markets. Equilibrium prices are proportional to the beginning of period money supply:

$$
\mathrm{P}_{\mathrm{st}}=\mathrm{p}_{\mathrm{s}} \mathrm{M}_{\mathrm{t}}
$$

where $P_{s t}$ is the dollar price in market $s$ and $p_{s}$ is the normalized price in market $\mathrm{s}$. The rate of inflation is the same for all markets and is given by:

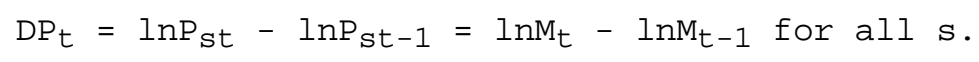


Note that since $M_{t}$ is the beginning of period money supply, prices adjust with a one period lag to changes in the money supply.

The average quoted price is given by:

$$
\mathrm{P}_{t}=\Sigma_{\mathrm{s}} \psi_{\mathrm{s}} \mathrm{P}_{\mathrm{st}}
$$

where $\psi_{\mathrm{S}}$ is the fraction of output allocated to market $s$. The variance of the log of prices is defined by:

$$
\operatorname{VAR}\left(\operatorname{lnP} P_{t}\right)=\Sigma \psi_{s}\left(\ln P_{t s}-\ln P_{t}\right)^{2}
$$

We define the stationary mean and variance of normalized prices by: $\operatorname{lnp}=\Sigma \psi_{\mathrm{S}} l \mathrm{lnp} \mathrm{p}_{\mathrm{S}}$ and $\operatorname{VAR}(\mathrm{lnp})=\Sigma \psi_{\mathrm{S}}\left(\mathrm{lnp} \mathrm{p}_{\mathrm{S}}-\operatorname{lnp}\right)^{2}$. Since $\mathrm{M}_{\mathrm{t}}$ is common across all markets we may use (9) to write:

$$
\operatorname{VAR}\left(\operatorname{lnP} P_{t}\right)=\operatorname{VAR}(\operatorname{lnp})
$$

This says that a shock to the money supply does not affect the variance of the log of dollar prices. Therefore, in response to a money supply shock we should observe an increase in the inflation rate (10) but no effect on the variance. Figure 3 illustrates. 


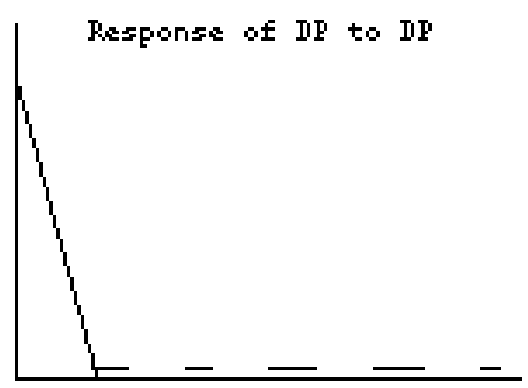

Response of SII to IIP

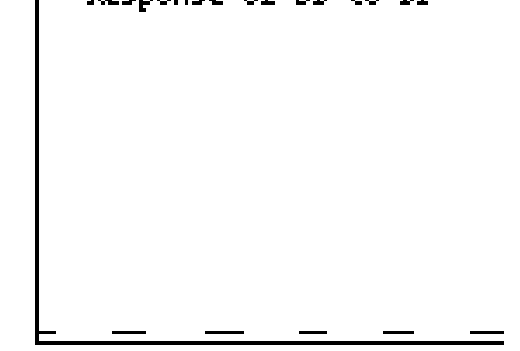

Figure 3: The response to a high realization of the money supply

When we allow for storage as in Bental and Eden (1996) we get a negative relationship between normalized prices and the beginning of period inventories. A high realization of the money supply leads to low inventories in the beginning of next period and high prices. The effect on inventories and prices dies out gradually. But there is no prediction about the relationship between inventories and price dispersion.

When i.i.d productivity shocks are added to the Bental and Eden (1996) model, equilibrium prices are a decreasing function of both the beginning of period inventories and the realization of the productivity shock (see Eden [forthcoming, chapter 17]). In this case a low realization of productivity leads to high prices but there is no prediction about the effect of productivity on price dispersion.

We may also consider the possibility of a permanent real shock. The effect of such a shock on the equilibrium relative price variability may be either positive or negative. It is possible for example that the real demand for a certain product went up and became more predictable. This will lead to an increase in the product specific inflation rate and to a decrease in relative price variability. Figure 4 illustrates the 
impulse response functions for this case. Note that the new equilibrium is achieved immediately after the shock.
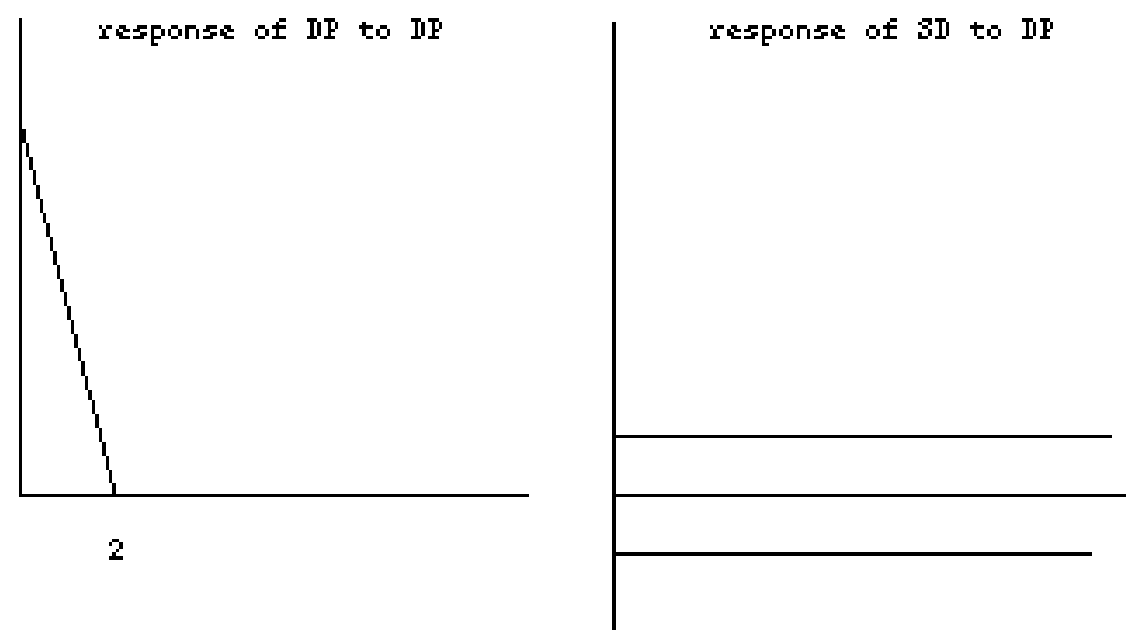

Figure 4: Possible responses to a permanent increase in demand

To sum up, we may say that to get a prediction about the response to an inflation shock we must make a stand about the nature of the shock. Since in our sample the rate of inflation is high we may expect that monetary shocks dominates at least in the earlier Lach and Tsiddon samples. We will therefore examine the hypothesis that the shock to inflation is due to a purely monetary shock as in Eden (1994).

\section{VECTOR AUTO REGRESSION ANALYSIS}

Figures 2-3 illustrate the difference in the predictions of the two models about the response to a shock to the inflation rate DP on DP itself and our measure of relative price variability, SD. In the 
staggered price setting model a shock to DP is expected to have a persistent effect on both DP and SD. The impact effect on SD is positive and this effect dies out when the effect on DP dies out.

In a simple monetary version of the UST model in Eden (1994) a shock to DP does not have a persistent effect on DP and has no effect on $\mathrm{SD}$.

We now test these predictions by running a VAR with two variables: DP and SD (in that order). We first allow for product specific coefficients and then impose the same coefficients on all products.

\section{Allowing for product specific coefficients:}

We start by running vector auto regressions for each product separately, allowing for four lags. We do this for the two high inflation periods in the Lach and Tsiddon (1992) data and for 21 products in the 91-92 moderate inflation sample. The 21 products which were chosen are a subset of the 26 products studied by Lach and Tsiddon. The typical VAR had 23 observations (months). In Figures 5-7 we compute the average impulse response (AV) across all the products in the sample. 5 We also calculated the standard deviation (STD) across products. The bounds in the Figures are: AV + STD (the average plus the standard deviation) and AV - STD. In all the samples the average DP returns to the baseline in the month following the shock. The average

5 This average was computed by obtaining the impulse response function in a Table form for each product and taking the average (AV) in each period across products. 
effect of a shock to DP on SD is close to zero. These findings are consistent with the theoretical impulse response functions from the UST model (Figure 3) but not with the staggered price setting model.

\section{Response of DP to DP}

Sample: $78-79$
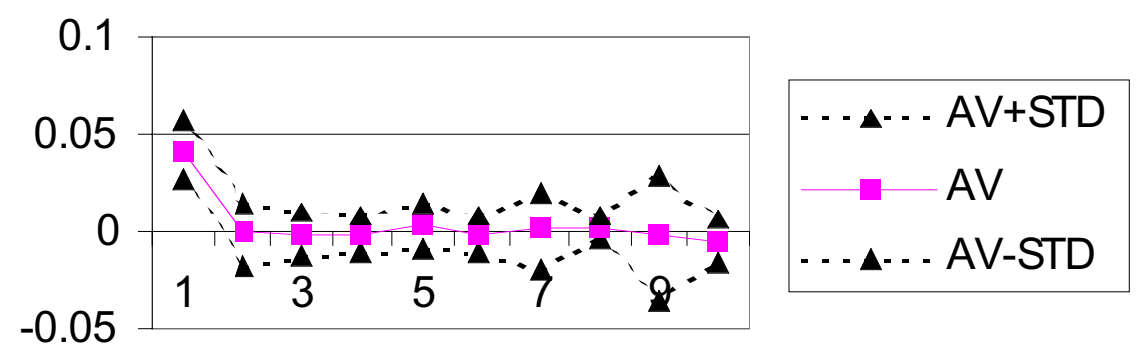

\section{Response of SD to DP Sample: $78-79$}

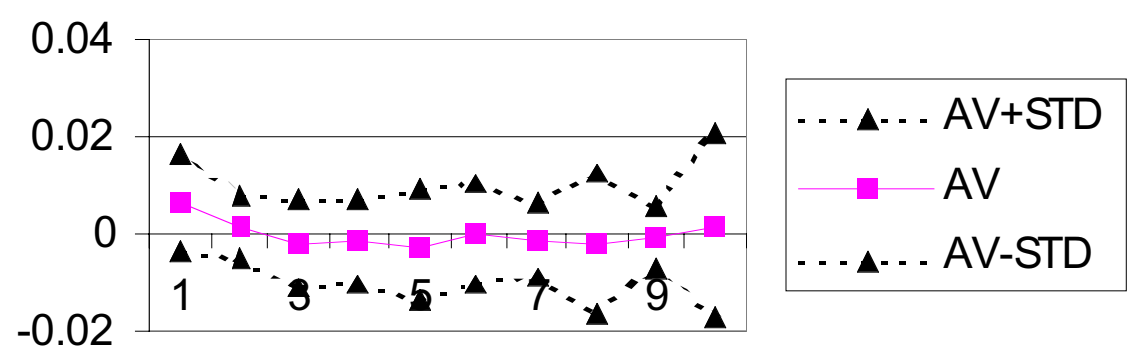

Figure 5: Average (across products) impulse response functions for the 1978-79 sample 

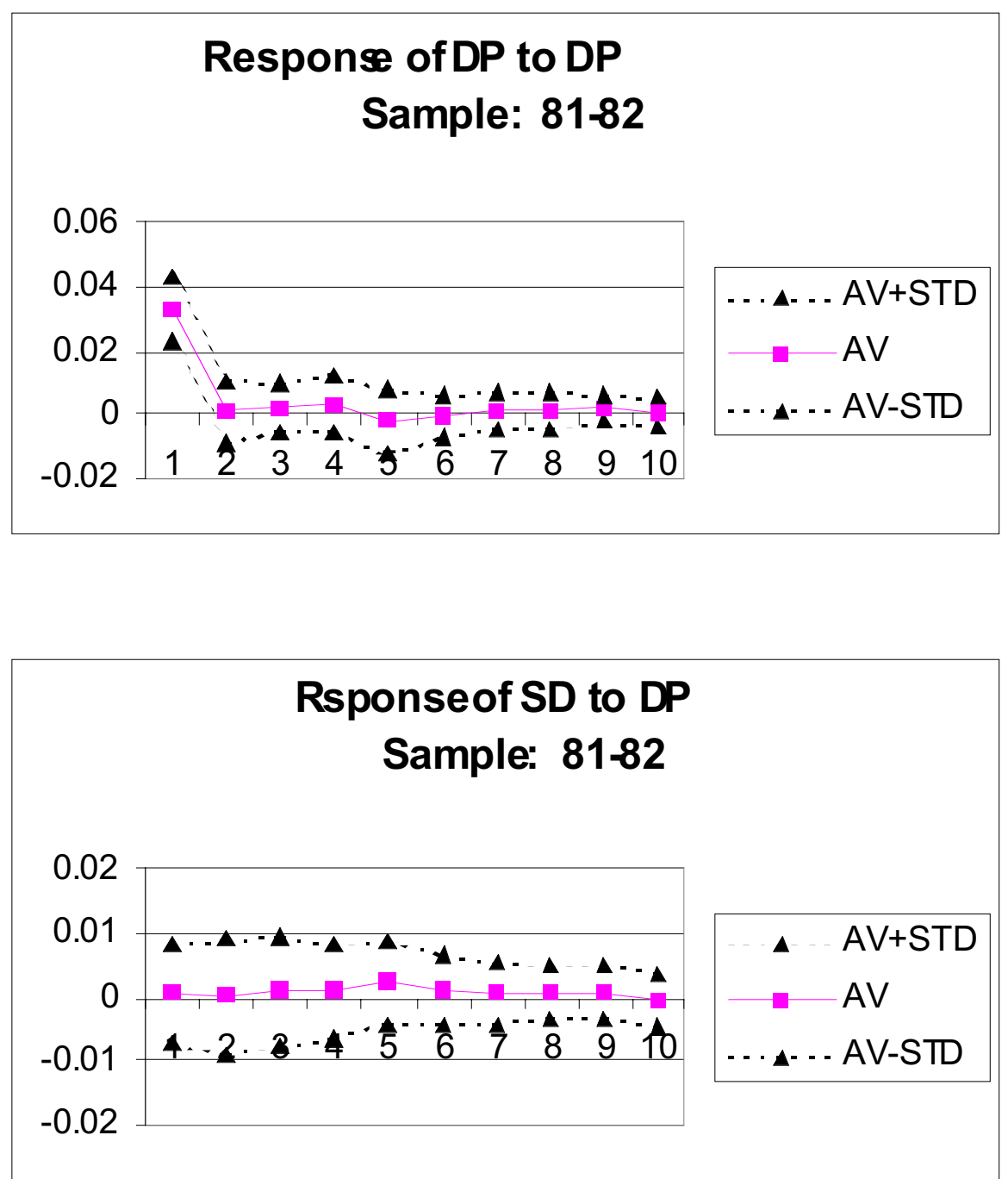

Figure 6: Average (across products) impulse response functions for the 1981-82 sample 

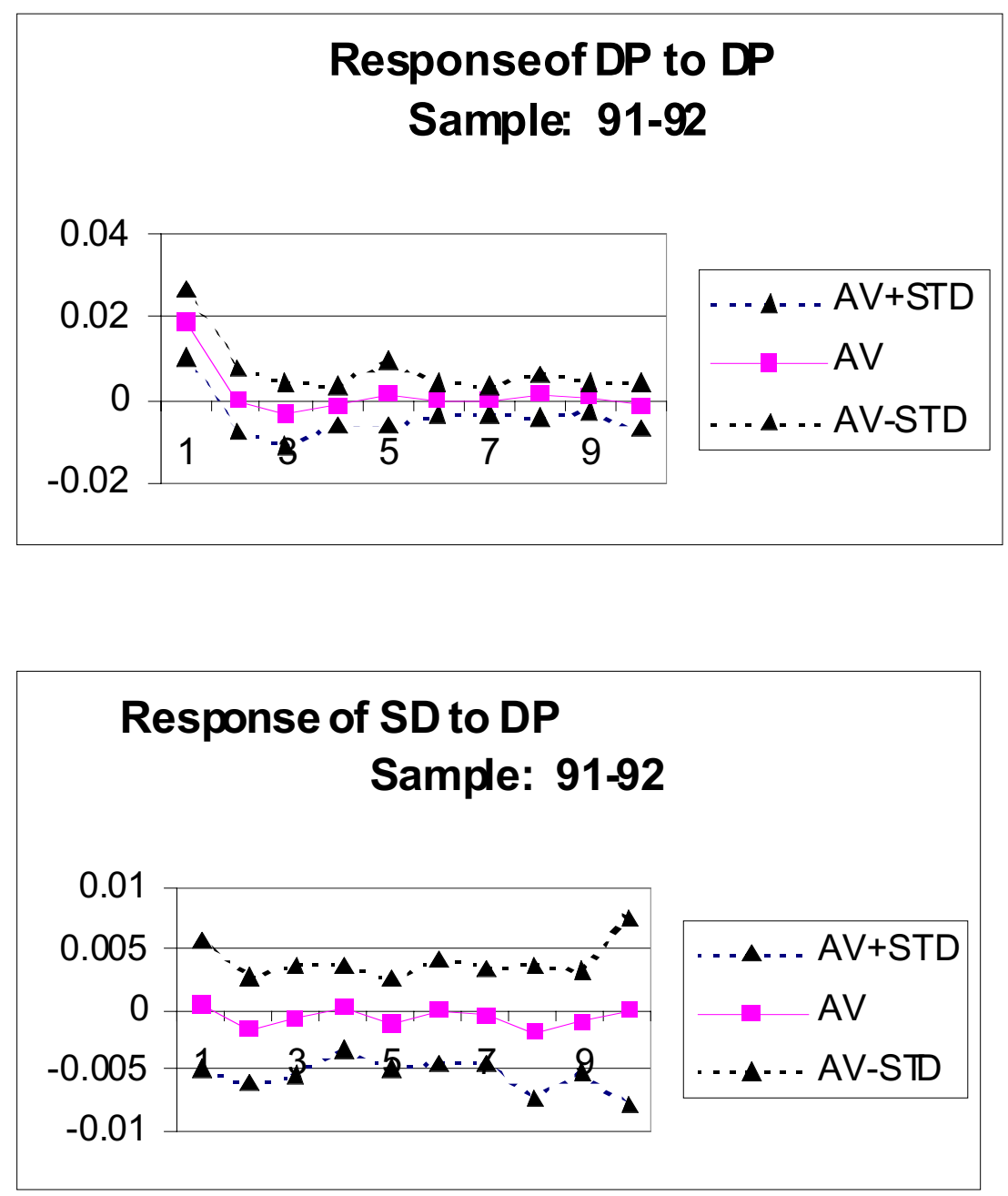

Figure 7: Average (across products) impulse response functions for the 1991-92 sample

Imposing the same coefficients on all products:

We now impose the same VAR coefficients across products. We may think of an hypothetical overlapping generations economy that lives for GT periods, where $G$ is the number of products in the sample (about 25 goods per sample) and $\mathrm{T}$ is the number of months (23). In this hypothetical economy each generation lives for $\mathrm{T}$ periods and consume one product only where the product changes every $\mathrm{T}$ periods. 
We created an artificial time series of about (23) (25) = 575 periods per sample and estimated two impulse response functions per sample. ${ }^{6}$ The results of this excercise are not reported here but the impulse response functions look very much like the average computed in Figures $5-7$ and may serve as a test for robustness.

\section{The 91-92 sample:}

We created an artificial time series of the type described above for 371 products in the 91-92 sample for which we have at least two observations about the direct measure of the length of the period $\Delta t$. The VAR regressions are:

$$
\begin{aligned}
& \mathrm{DP}=\mathrm{C}-0.14^{\star} \mathrm{DP}_{-1}-0.10^{\star} \mathrm{DP}_{-2}-0.07^{*} \mathrm{DP}_{-3}-0.07^{\star} \mathrm{DP}_{-4} \\
&+0.06^{\star} \mathrm{SD}_{-1}-0.03^{\star} \mathrm{SD}_{-2}-0.03^{\star} \mathrm{SD}_{-3}+0.004 \mathrm{SD}_{-4}
\end{aligned}
$$

$\operatorname{Adj} \cdot R^{2}=0.035$

$$
\begin{aligned}
\mathrm{SD}=\mathrm{C} & +0.02 \mathrm{DP}_{-1}+0.01 \mathrm{DP}_{-2}+0.01 \mathrm{DP}-3+0.02 \mathrm{DP}_{-4} \\
& +0.67^{\star} \mathrm{SD}_{-1}+0.16^{\star} \mathrm{SD}_{-2}+0.10^{\star} \mathrm{SD}_{-3}+0.07^{\star} \mathrm{SD}_{-4}
\end{aligned}
$$

Number of observations $=6897, \mathrm{Adj} \cdot \mathrm{R}^{2}=0.988$

The coefficients with an astrik are significant (t values over 2). Note that individual lags of DP are not significant in the SD equation. Note also that the coefficients of the lag DP in the DP equation are all

\footnotetext{
6 We separate each good by blanks so that the lags of product i will not be taken as observations from product i-1.
} 
negative. Finally, we note the difference in the $\mathrm{R}^{2}$. It is almost unity in the SD equation and almost zero in the DP equation.

The impulse response functions are in Figure 8. A shock in DP has a small persistent negative effect on DP that lasts for 4 months. ${ }^{7}$ It also has a small negative effect on SD. This strongly contradicts the implications of the staggered price setting model. The estimated impulse response functions are also not consistent with the UST model because of the persistent negative effect of the shock on the inflation rate.

We now split the sample into two according to a measure of price rigidity $1 / E_{t}\left(x_{i t}\right)$. In Figure 9 we used an artificial time series which is made from the less "rigid" products (with lower $1 / \mathrm{E}_{t}\left(\mathrm{x}_{i t}\right)$ ). In Figure 10 we used the more "rigid" products. A shock to the inflation rate has a persistent effect on the inflation rate for the less "rigid" products but no persistent effect on the inflation rate for the more "rigid" products. The estimated impulse responses for more "rigid" products are consistent with the UST predictions.

\section{CONCLUSIONS}

We used monthly Israeli data about price changes by product and stores for 381 products over 23 months (February 1991 to December 1992). The estimated average length of the period (spell of unchanged price) is 4.1 months when using the average frequency and more than 7.5 months

7 The average SD reported in Table 1 is 0.27 . The permanent effect of the shock on SD is about 0.0025 which is close to $1 \%$ of the average SD. 
when attempting to correct for an aggregation bias which is due to Jensen's inequality. Thus, estimates of the length of the period (spell of unchanged prices) which use the average frequency of price change may be seriously downward biased.

We also looked at direct measures of the length of the period $\Delta t$. We find that store characteristics are as important as product characteristics in determining the length of the period. When we control for the average jump in the price (average for the store and for the product) we do not find a positive relationship between the size of the current jump to the time since the last jump. This is surprising because most sticky price models assume that stores change their price by the real price depreciation since the last price change episode.

Finally we ask whether prices are realy rigid as in the staggered price setting litarature or just seemingly rigid as in the uncertain and sequential trade literature. We find no support for the real rigidity hypothesis. There is no clear relationship between the average frequency of nominal price changes and price dispersion. And the estimated effect of a shock to the inflation rate does not look like the prediction from the staggered price setting model.

The estimated effect of a shock to the inflation rate does not look very different from the predicted effect of a monetary shock in the UST model (Figure 3). For the earlier high inflation periods and for the comparable sample of goods in the moderate inflation period the estimated effect is very close to the prediction. For the 1991-92 sample as a whole, a shock to the inflation rate seems to have a persistent small negative effect on price dispersion. 
Figure 8: Impulse response to an inflation shock for 371 products in the 1991-92 sample

Response to One S.D. Innov ations \pm 2 S.E.

Response of DP to DP

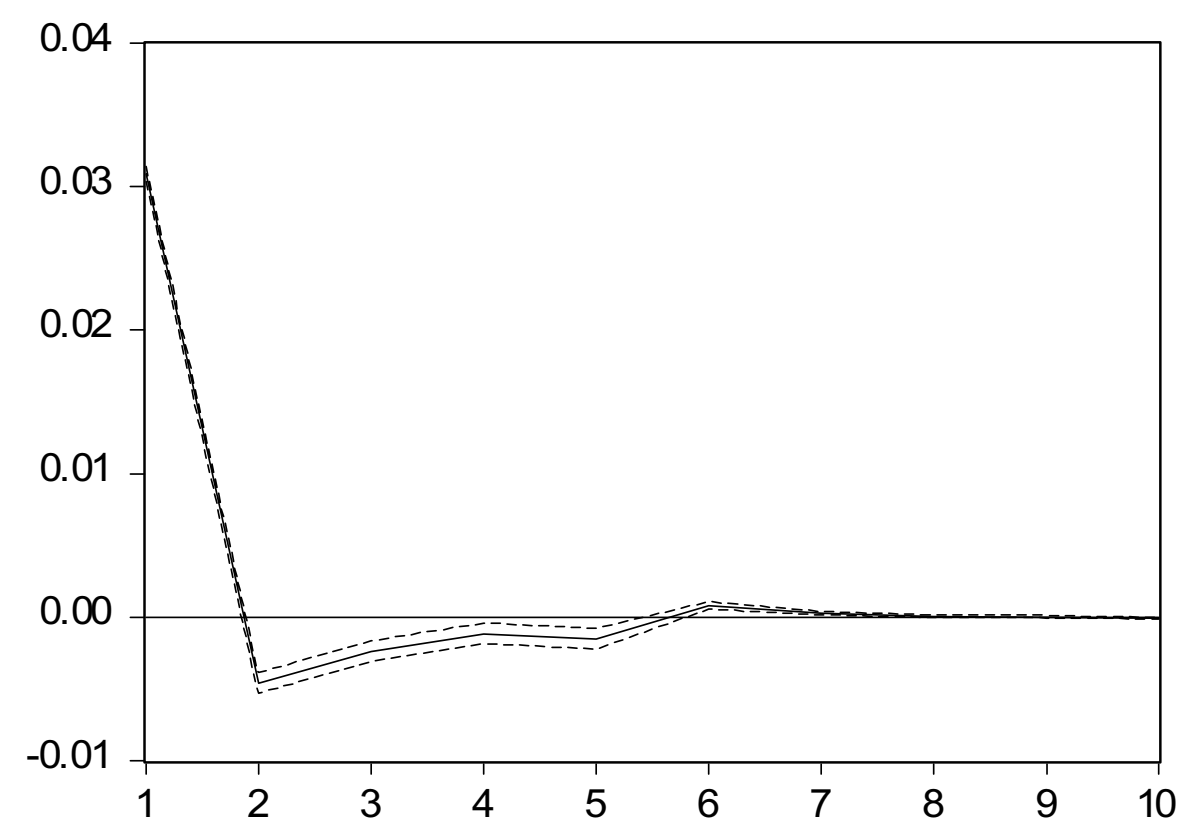

Response of SD to DP

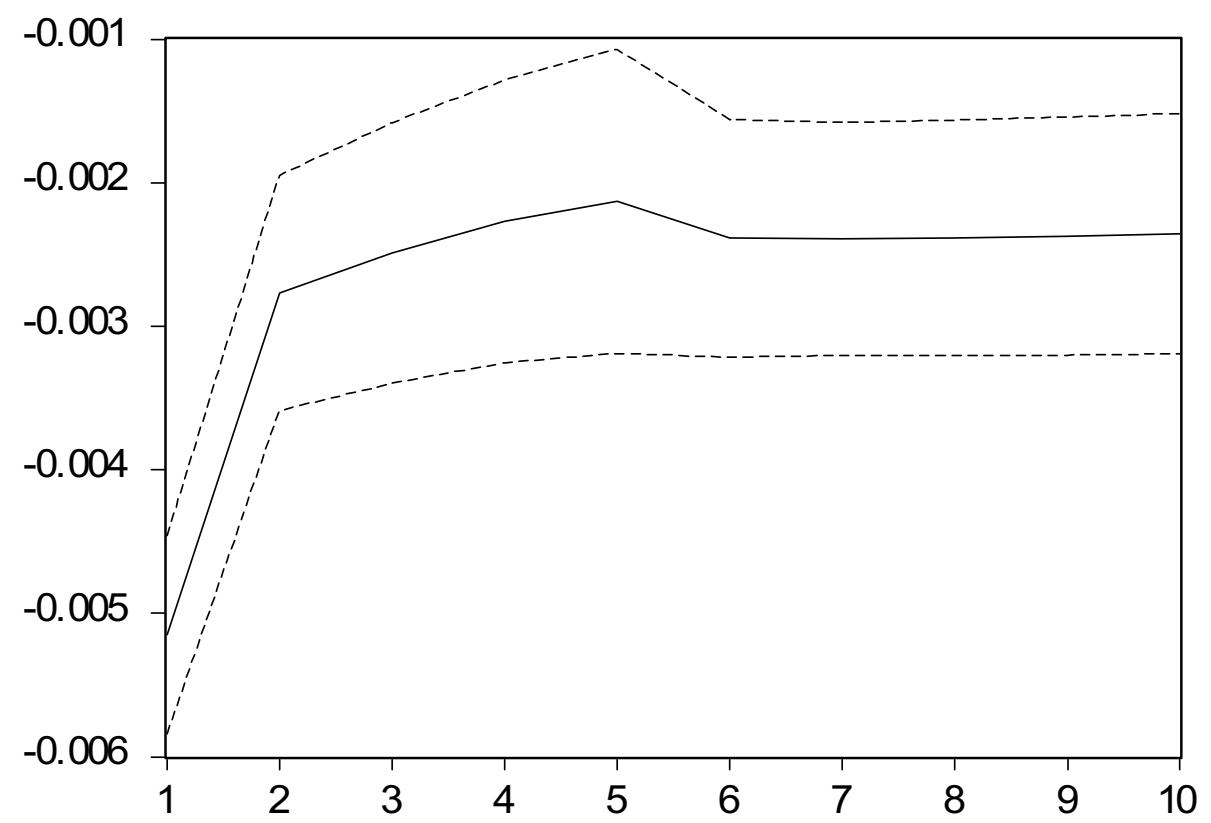


Figure 9: The impulse response for the "less rigid" product in the 1991-92 sample

Response to One S.D. Innovations \pm 2 S.E.

Response of DP to DP

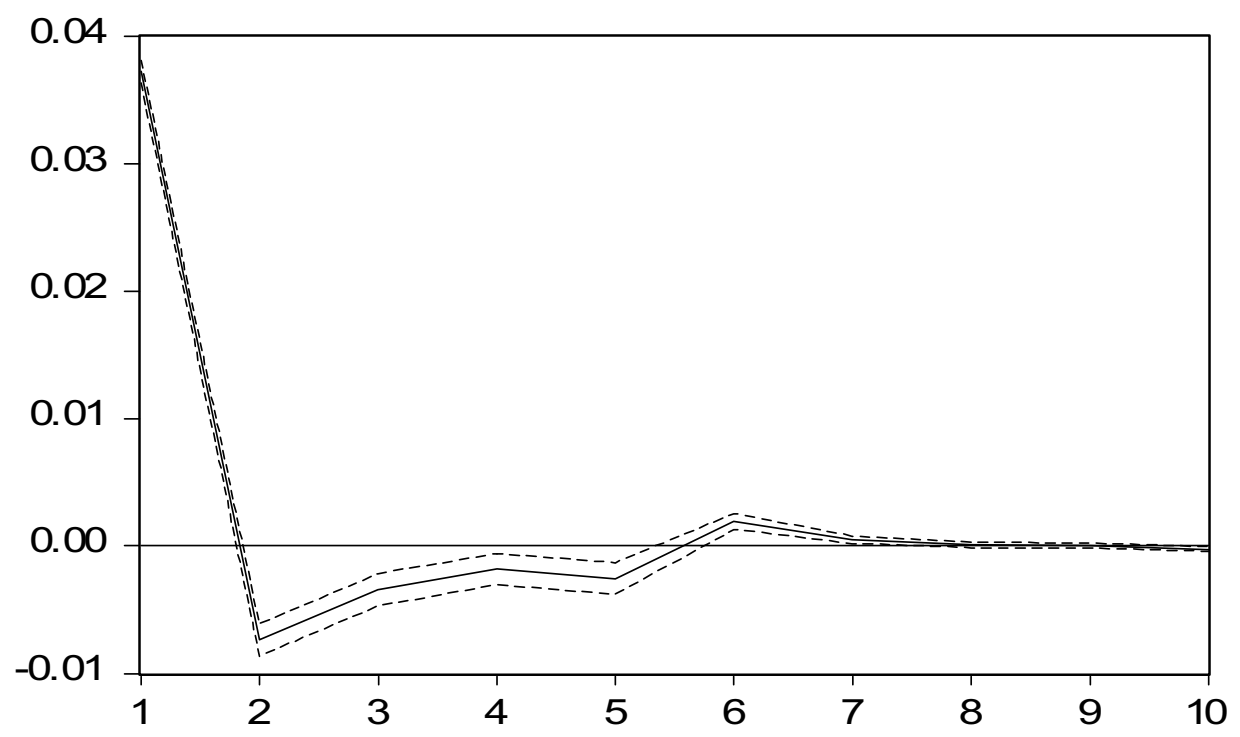

Response of SD to DP

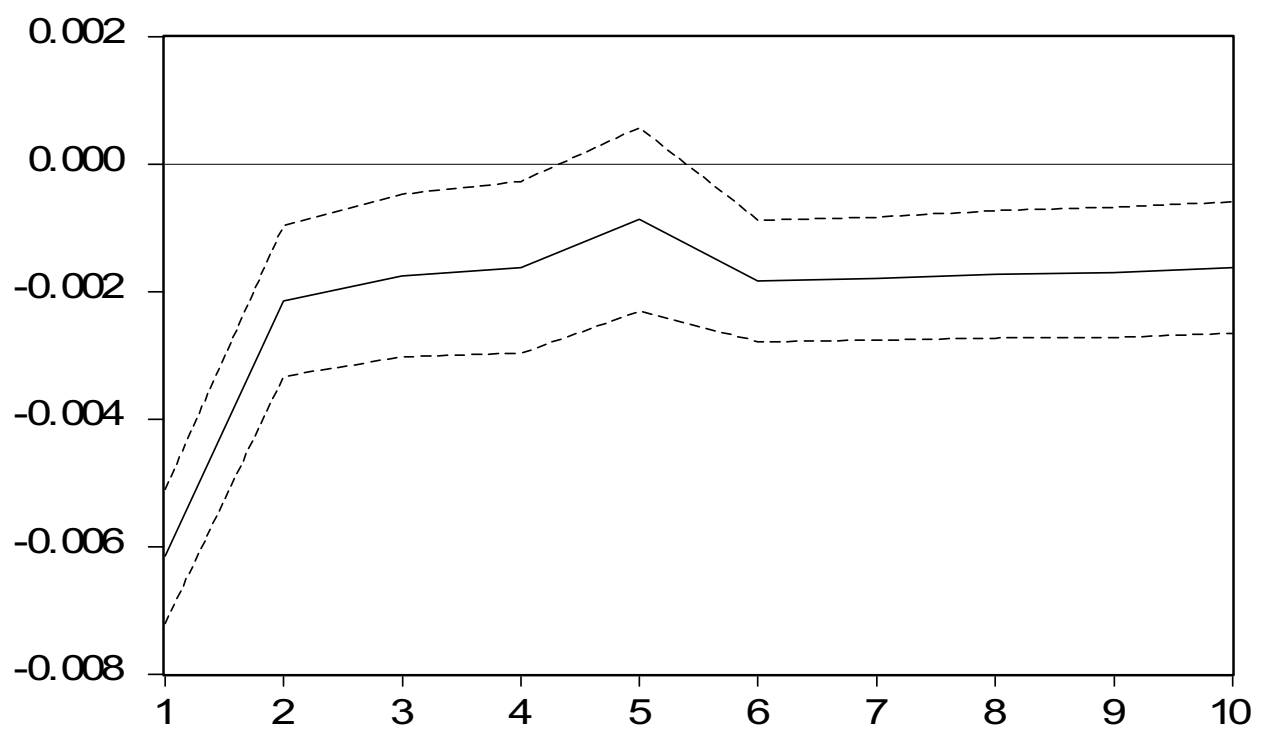


Figure 10: Impulse response function for the more "rigid" products in the 1991-92 sample

Response to One S.D. Innovations \pm 2 S.E.

Response of DP to DP

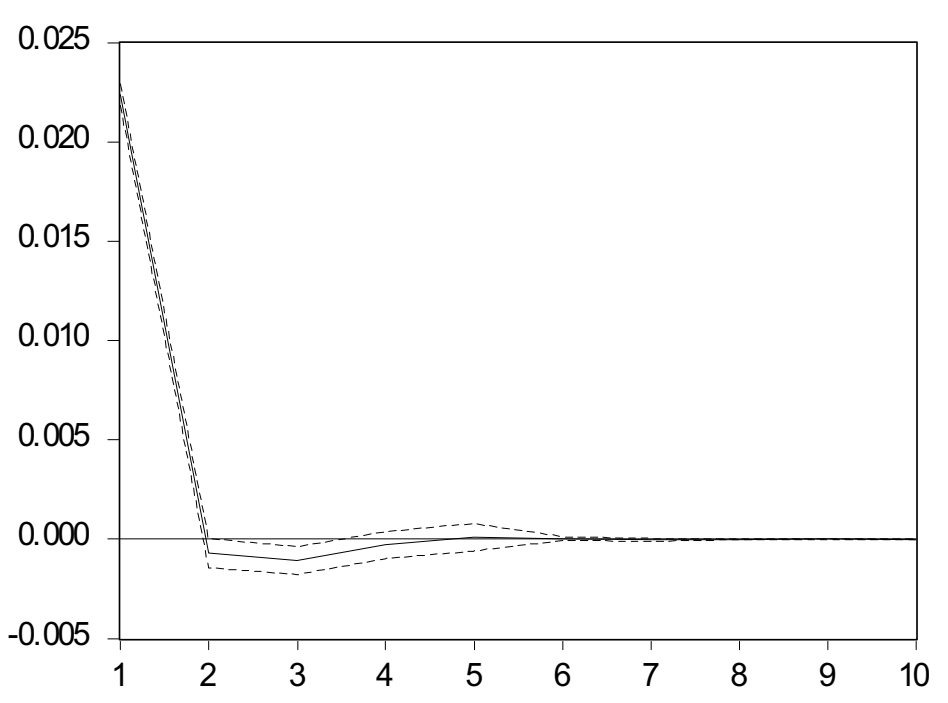

Response of SD to DP

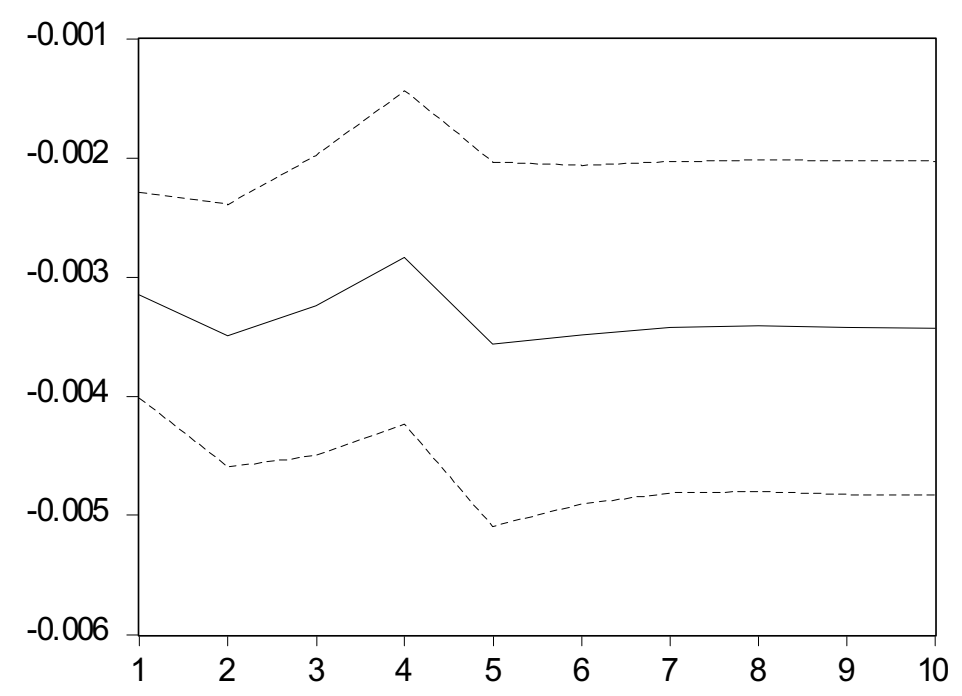


TABLE 1: PRICE DISPERSION AND MEASURES OF THE LENGTH OF THE PERIOD BY PRODUCT

Notes:

1. The product name was translated from hebrew and is abbreviated here. For example, product 105 in the original description is: Citrus fruit drink, pasteurized, does not include pure fruit juice. We abbreviated and wrote citrus fruit drink.

2. The product number was given by the Israeli central bureau of statistic.

3. \# of stores is the number of stores which reported their price for the product.

4. freq $=E_{t}\left(x_{i t}\right)$ is the average number of stores that changed their nominal price (for product i) per month.

5. $S D(l n p)$ is the average (over months) standard deviation of lnp. We computed the standard deviation of $\mathrm{lnp}$ across stores for each month and then took the average over 23 months.

6. \# obser of $\Delta t$ is the number of direct observation about the length of the period.

7. $\mathrm{AV} \Delta \mathrm{t}$ is the average of the direct observation about the length of the period.

8. $\mathrm{SD}(\Delta \mathrm{t})$ is the standard deviation of $\Delta t$.

9. $1 /$ freq $=1 / E_{t}\left(x_{i t}\right)$ is an estimate of the length of the period obtain as one over the average computed in 4.

10. $E_{t}\left(1 / x_{i t}\right)$ is the average (over months) of 1 over the monthly frequency. This measure was computed only for products with strictly positive $x_{\text {it }}$ for all $t$.

11. The product inflation rate (percent per month). 


\begin{tabular}{|c|c|c|c|c|c|c|c|c|c|c|}
\hline Product name (abb.) & $\begin{array}{l}\text { Prod. } \\
\#\end{array}$ & $\begin{array}{l}\text { \# of } \\
\text { stores }\end{array}$ & $\begin{array}{l}\text { freq }= \\
E_{t}\left(x_{i t}\right)\end{array}$ & $\begin{array}{l}\text { SD } \\
\text { (Inp) }\end{array}$ & $\begin{array}{l}\text { \# obs. } \\
\text { of } d t\end{array}$ & $\begin{array}{l}\text { av. } \\
\mathrm{dt}\end{array}$ & $\begin{array}{l}S D \\
\text { (dt) }\end{array}$ & $\begin{array}{l}1 / \text { freq }= \\
1 / \text { Et }\left(x_{i t}\right)\end{array}$ & $\begin{array}{l}E_{t} \\
\left(1 / x_{i t}\right)\end{array}$ & $\begin{array}{l}\text { av. } \\
\text { inflation }\end{array}$ \\
\hline AVERAGE & & 7.1 & 0.24 & 0.27 & 37.1 & 4.0 & 2.8 & 5.8 & 3.5 & 0.79 \\
\hline STANDARD DEVIATION & & 5.0 & 0.15 & 0.26 & 49.5 & 2.1 & 1.4 & 3.8 & 1.3 & 0.44 \\
\hline MEDIAN & & 5 & 0.20 & 0.18 & 21 & 3.3 & 2.5 & 4.6 & 3.4 & 0.78 \\
\hline Gasoline 91 octane & 31001 & 12 & 0.92 & 0.01 & 241 & 1.1 & 0.3 & 1.1 & . & 1.04 \\
\hline Gasoline 96 octane & 31002 & 12 & 0.87 & 0.01 & 229 & 1.1 & 0.3 & 1.1 & . & 0.96 \\
\hline Kerosene, home use & 31004 & 6 & 0.83 & 0.01 & 108 & 1.2 & 0.4 & 1.2 & . & -0.09 \\
\hline Fresh chicken & 3002 & 21 & 0.68 & 0.16 & 308 & 1.4 & 0.9 & 1.5 & 1.6 & 0.95 \\
\hline Frozen chicken & 3001 & 23 & 0.68 & 0.07 & 337 & 1.4 & 0.8 & 1.5 & 1.6 & 0.62 \\
\hline Tylenol & 24001 & 1 & 0.65 & & 14 & 1.5 & 0.7 & 1.5 & & 0.79 \\
\hline Chicken parts & 3006 & 28 & 0.65 & 0.14 & 391 & 1.4 & 0.8 & 1.5 & 1.7 & 0.79 \\
\hline Turkey & 3009 & 15 & 0.62 & 0.14 & 199 & 1.5 & 1.3 & 1.6 & 1.8 & -0.25 \\
\hline Frozen vegetables & 2011 & 2 & 0.61 & 0.17 & 26 & 1.5 & 1.1 & 1.6 & & 0.14 \\
\hline Carbonated drink & 108 & 5 & 0.60 & 0.11 & 64 & 1.6 & 1.1 & 1.7 & 2.1 & 1.70 \\
\hline Corn, Israeli & 125 & 3 & 0.59 & 0.12 & 38 & 1.7 & 1.3 & 1.7 & & -0.18 \\
\hline Chicken breasts & 3003 & 28 & 0.59 & 0.18 & 349 & 1.6 & 1.0 & 1.7 & 1.9 & 0.30 \\
\hline Liquid detergent & 10028 & 7 & 0.57 & 0.15 & 85 & 1.7 & 1.2 & 1.8 & 1.9 & 0.58 \\
\hline Coca Cola & 107 & 13 & 0.55 & 0.08 & 150 & 1.8 & 1.4 & 1.8 & 2.3 & 1.26 \\
\hline Jam & 133 & 11 & 0.53 & 0.07 & 124 & 1.8 & 1.7 & 1.9 & 2.2 & 1.28 \\
\hline Wine & 6007 & 9 & 0.52 & 0.11 & 99 & 1.9 & 2.1 & 1.9 & 2.3 & 0.71 \\
\hline Toilet paper & 10017 & 12 & 0.52 & 0.87 & 131 & 1.6 & 1.5 & 1.9 & 2.3 & 0.23 \\
\hline Sweetened drink & 109 & 15 & 0.51 & 0.12 & 162 & 1.7 & 1.1 & 1.9 & 2.1 & 1.23 \\
\hline Chocolate milk & 5511 & 6 & 0.51 & 0.15 & 64 & 1.8 & 1.1 & 2.0 & & 1.71 \\
\hline Chicken liver & 3004 & 18 & 0.50 & 0.10 & 191 & 1.8 & 1.3 & 2.0 & 2.5 & 1.10 \\
\hline Turkey thighs & 3008 & 16 & 0.50 & 0.20 & 168 & 1.7 & 1.5 & 2.0 & 2.2 & 0.67 \\
\hline Acne medication & 24020 & 2 & 0.50 & 0.02 & 21 & 2.0 & 1.1 & 2.0 & & 0.85 \\
\hline Instant coffee & 6505 & 15 & 0.50 & 0.34 & 156 & 2.0 & 1.5 & 2.0 & 2.3 & 0.74 \\
\hline Honey & 101 & 3 & 0.49 & 0.07 & 31 & 1.8 & 1.3 & 2.0 & & 2.94 \\
\hline Carbonated water & 110 & 11 & 0.49 & 0.08 & 112 & 1.9 & 1.5 & 2.1 & 2.4 & 1.33 \\
\hline Birth control pills & 24009 & 2 & 0.48 & 0.01 & 20 & 1.9 & 1.5 & 2.1 & . & 0.59 \\
\hline Tranquilizers & 24010 & 2 & 0.48 & 0.88 & 20 & 2.0 & 1.3 & 2.1 & . & 0.78 \\
\hline Nasal decongestant & 24023 & 2 & 0.48 & 0.01 & 20 & 1.9 & 1.2 & 2.1 & . & 0.98 \\
\hline Chocolate milk, Israeli & 5510 & 13 & 0.47 & 0.05 & 129 & 1.9 & 1.2 & 2.1 & 3.0 & 1.23 \\
\hline Ketchup & 120 & 11 & 0.47 & 0.22 & 107 & 2.0 & 1.5 & 2.1 & 2.6 & 0.70 \\
\hline Detergent & 10009 & 8 & 0.46 & 0.24 & 77 & 1.9 & 1.7 & 2.2 & 2.5 & 0.25 \\
\hline Refrigerator, imported & 14012 & 2 & 0.46 & 0.54 & 19 & 1.9 & 1.9 & 2.2 & & 0.95 \\
\hline Citrus fruit drink & 105 & 7 & 0.45 & 0.34 & 65 & 2.2 & 1.5 & 2.2 & 3.4 & 1.68 \\
\hline Chocolate milk & 5512 & 11 & 0.45 & 0.04 & 102 & 2.1 & 1.3 & 2.2 & & 1.48 \\
\hline Snacks & 5509 & 6 & 0.44 & 0.35 & 55 & 1.9 & 1.2 & 2.3 & & 1.25 \\
\hline Fruit jam & 102 & 7 & 0.44 & 0.07 & 64 & 2.2 & 2.0 & 2.3 & & 0.77 \\
\hline Chicken parts & 3005 & 15 & 0.44 & 0.48 & 136 & 2.0 & 2.0 & 2.3 & 2.6 & 0.15 \\
\hline fish & 4002 & 2 & 0.43 & 0.01 & 18 & 2.0 & 1.5 & 2.3 & . & 1.58 \\
\hline Waffle & 5507 & 1 & 0.43 & . & 9 & 1.6 & 0.8 & 2.3 & . & 0.88 \\
\hline Antibiotic & 24007 & 2 & 0.43 & 0.01 & 18 & 2.1 & 1.2 & 2.3 & . & 0.66 \\
\hline Insecticide & 10013 & 15 & 0.43 & 0.15 & 132 & 2.0 & 1.8 & 2.3 & 2.8 & 0.41 \\
\hline Biscuits & 5506 & 7 & 0.42 & 0.38 & 61 & 2.0 & 1.2 & 2.4 & . & 1.14 \\
\hline Frozen French fries & 2013 & 3 & 0.42 & 0.06 & 26 & 2.3 & 2.2 & 2.4 & . & 0.85 \\
\hline Detergent & 10010 & 2 & 0.41 & 0.21 & 17 & 2.0 & 1.7 & 2.4 & . & 0.80 \\
\hline Toothpaste & 10024 & 4 & 0.41 & 0.22 & 34 & 2.4 & 2.4 & 2.4 & & 0.81 \\
\hline Frozen soup & 2010 & 5 & 0.41 & 0.05 & 42 & 2.3 & 1.8 & 2.4 & & 0.66 \\
\hline Iced cream & 4526 & 3 & 0.41 & 0.36 & 25 & 2.0 & 1.8 & 2.5 & & 0.60 \\
\hline
\end{tabular}




\begin{tabular}{|c|c|c|c|c|c|c|c|c|c|c|}
\hline Brandy & 6009 & 9 & 0.41 & 0.15 & 75 & 1.9 & 1.9 & 2.5 & 3.8 & 0.75 \\
\hline Crackers & 5508 & 7 & 0.40 & 0.12 & 58 & 2.2 & 1.2 & 2.5 & & 0.94 \\
\hline Instant cocoa & 6502 & 7 & 0.40 & 0.25 & 58 & 2.2 & 2.2 & 2.5 & 3.0 & 0.52 \\
\hline Canned baby food, Gerber & 131 & 8 & 0.40 & 0.11 & 66 & 2.1 & 1.4 & 2.5 & 3.4 & 0.40 \\
\hline Sugar substitutes & 6702 & 4 & 0.40 & 0.23 & 33 & 2.5 & 2.3 & 2.5 & & 0.54 \\
\hline Green olives & 113 & 5 & 0.40 & 0.21 & 41 & 2.2 & 1.7 & 2.5 & & 0.92 \\
\hline Frozen fish & 4008 & 10 & 0.40 & 0.09 & 82 & 2.2 & 2.6 & 2.5 & & 0.16 \\
\hline Soup mix & 6707 & 10 & 0.40 & 0.61 & 81 & 2.2 & 1.7 & 2.5 & 3.3 & 0.80 \\
\hline Instant pudding & 525 & 11 & 0.40 & 0.05 & 89 & 2.1 & 1.5 & 2.5 & 3.8 & 1.41 \\
\hline Pickles, canned & 115 & 4 & 0.39 & 0.18 & 32 & 2.1 & 2.0 & 2.6 & & 0.82 \\
\hline Frozen pizza & 2007 & 3 & 0.39 & 0.32 & 24 & 2.3 & 1.8 & 2.6 & . & -0.02 \\
\hline Chocolate milk & 5513 & 12 & 0.39 & 0.08 & 96 & 2.3 & 1.5 & 2.6 & . & 1.44 \\
\hline Microwave & 14020 & 2 & 0.39 & 0.20 & 16 & 2.4 & 1.7 & 2.6 & & 0.34 \\
\hline Disposable diapers & 10021 & 8 & 0.39 & 0.07 & 63 & 2.1 & 1.3 & 2.6 & 3.6 & 0.35 \\
\hline Liver, beef & 1505 & 9 & 0.38 & 0.08 & 70 & 2.2 & 1.6 & 2.6 & & 1.90 \\
\hline Dried rice & 523 & 6 & 0.38 & 0.05 & 46 & 2.1 & 1.4 & 2.7 & & 1.40 \\
\hline Cookies & 5504 & 2 & 0.37 & 0.01 & 15 & 2.4 & 2.0 & 2.7 & & 0.96 \\
\hline Turkey breasts & 3007 & 15 & 0.37 & 0.18 & 112 & 2.2 & 2.1 & 2.7 & 2.9 & 0.57 \\
\hline Cornflakes & 536 & 5 & 0.37 & 0.12 & 37 & 2.6 & 2.1 & 2.7 & & 1.20 \\
\hline Noodles & 531 & 9 & 0.36 & 0.21 & 66 & 2.7 & 1.8 & 2.8 & 3.8 & 1.35 \\
\hline Deodorizer & 10014 & 9 & 0.36 & 0.16 & 67 & 2.0 & 1.3 & 2.8 & 3.6 & -0.11 \\
\hline Plastic paint & 11001 & 3 & 0.36 & 0.08 & 22 & 2.6 & 1.7 & 2.8 & & 0.39 \\
\hline Floor cleaner & 10007 & 7 & 0.36 & 0.32 & 51 & 2.6 & 2.2 & 2.8 & . & 0.47 \\
\hline Vinegar & 6712 & 8 & 0.36 & 0.06 & 58 & 2.6 & 1.8 & 2.8 & . & 1.43 \\
\hline Washing machine & 14008 & 4 & 0.36 & 0.14 & 29 & 2.8 & 2.0 & 2.8 & . & 1.17 \\
\hline Toilettes & 10019 & 9 & 0.36 & 0.56 & 66 & 1.9 & 1.2 & 2.8 & 3.4 & 0.27 \\
\hline Frozen vegetables & 2012 & 5 & 0.36 & 0.27 & 36 & 2.8 & 2.7 & 2.8 & . & 0.57 \\
\hline Filet & 4006 & 11 & 0.36 & 0.23 & 79 & 2.8 & 3.2 & 2.8 & . & 0.59 \\
\hline Dish cleaner, liquid & 10002 & 11 & 0.36 & 0.39 & 79 & 2.2 & 1.9 & 2.8 & 3.1 & 0.52 \\
\hline Toothpaste, Israeli & 10023 & 22 & 0.35 & 0.28 & 155 & 2.3 & 2.0 & 2.9 & 3.7 & 0.82 \\
\hline Natural fruit juice & 106 & 6 & 0.35 & 0.09 & 42 & 2.1 & 1.6 & 2.9 & & 1.13 \\
\hline Beer & 6014 & 5 & 0.35 & 0.17 & 35 & 2.1 & 1.3 & 2.9 & & 0.90 \\
\hline Superlack & 11002 & 3 & 0.35 & 0.05 & 21 & 2.5 & 1.7 & 2.9 & & 0.88 \\
\hline Moisturizer & 32503 & 3 & 0.35 & 0.54 & 21 & 2.0 & 1.6 & 2.9 & & 1.01 \\
\hline Detergent & 10012 & 11 & 0.34 & 0.31 & 76 & 2.8 & 1.9 & 2.9 & . & 1.08 \\
\hline Cookies & 5505 & 10 & 0.34 & 0.03 & 69 & 2.7 & 2.1 & 2.9 & . & 0.87 \\
\hline Pudding & 524 & 9 & 0.34 & 0.12 & 62 & 2.3 & 2.1 & 2.9 & . & 1.04 \\
\hline Jam, Israeli & 103 & 13 & 0.34 & 0.18 & 89 & 2.6 & 1.9 & 2.9 & . & 0.62 \\
\hline Granola & 537 & 5 & 0.34 & 0.08 & 34 & 3.0 & 2.1 & 2.9 & . & 0.75 \\
\hline Cleaning agents & 10006 & 10 & 0.34 & 0.13 & 68 & 2.3 & 1.4 & 2.9 & . & 1.15 \\
\hline TV set & 14006 & 4 & 0.34 & 0.10 & 27 & 3.0 & 2.3 & 3.0 & 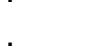 & 0.97 \\
\hline Dough & 532 & 9 & 0.33 & 0.28 & 60 & 2.8 & 2.2 & 3.0 & 3.7 & 1.13 \\
\hline Macaroni & 530 & 8 & 0.33 & 0.32 & 53 & 2.7 & 1.8 & 3.0 & & 1.01 \\
\hline Soup mix & 6708 & 9 & 0.33 & 0.85 & 59 & 2.2 & 1.9 & 3.0 & 4.4 & 0.65 \\
\hline Aluminum foil & 10020 & 9 & 0.33 & 0.34 & 59 & 2.0 & 1.6 & 3.0 & & 0.37 \\
\hline Refrigerator & 14010 & 15 & 0.32 & 0.05 & 97 & 2.9 & 2.2 & 3.1 & 4.3 & 0.56 \\
\hline Eggs & 5006 & 5 & 0.32 & 1.40 & 32 & 2.7 & 1.5 & 3.1 & & 1.41 \\
\hline Fish & 4001 & 8 & 0.32 & 0.08 & 51 & 2.5 & 1.8 & 3.1 & 4.6 & 1.18 \\
\hline Shoe polish & 10025 & 16 & 0.32 & 0.30 & 102 & 2.8 & 2.8 & 3.1 & & 1.56 \\
\hline Detergent & 10008 & 14 & 0.32 & 0.27 & 89 & 2.5 & 1.4 & 3.1 & . & 1.12 \\
\hline Iced cream & 4527 & 3 & 0.32 & 0.26 & 19 & 2.3 & 1.9 & 3.1 & . & 0.87 \\
\hline Chrysanthemum & 17003 & 3 & 0.32 & 0.36 & 18 & 1.2 & 0.5 & 3.1 & r. & 1.00 \\
\hline Soup nuts & 514 & 10 & 0.32 & 0.57 & 63 & 2.9 & 2.4 & 3.2 & 4.1 & 0.92 \\
\hline Tomato paste & 119 & 14 & 0.32 & 0.45 & 88 & 2.0 & 2.0 & 3.2 & 4.2 & 1.03 \\
\hline
\end{tabular}




\begin{tabular}{|c|c|c|c|c|c|c|c|c|c|c|}
\hline Soy oil & 5001 & 8 & 0.32 & 0.13 & 50 & 2.8 & 2.2 & 3.2 & & 0.98 \\
\hline TV set & 14005 & 8 & 0.32 & 0.16 & 50 & 2.8 & 2.3 & 3.2 & 4.2 & 0.59 \\
\hline Mayonnaise & 5011 & 8 & 0.31 & 0.04 & 49 & 2.7 & 2.1 & 3.2 & 4.8 & 0.50 \\
\hline Scotch bright & 10004 & 18 & 0.31 & 0.78 & 111 & 2.3 & 2.0 & 3.2 & 4.9 & 0.79 \\
\hline Candy & 5520 & 5 & 0.30 & 0.15 & 30 & 2.9 & 2.1 & 3.3 & & 1.10 \\
\hline Sauce & 6711 & 8 & 0.30 & 0.12 & 48 & 2.8 & 2.2 & 3.3 & . & 1.11 \\
\hline Nose drops & 24004 & 2 & 0.30 & 0.01 & 12 & 2.6 & 1.4 & 3.3 & . & 0.80 \\
\hline Medication for indigestion & 24025 & 2 & 0.30 & 0.28 & 12 & 2.7 & 1.9 & 3.3 & & 0.63 \\
\hline Bleach & 10005 & 14 & 0.30 & 0.42 & 82 & 2.7 & 2.5 & 3.4 & & 0.42 \\
\hline Washing machine & 14007 & 13 & 0.30 & 0.05 & 76 & 3.3 & 2.5 & 3.4 & 5.0 & 0.96 \\
\hline Tehina & 5012 & 10 & 0.30 & 0.17 & 58 & 2.3 & 1.9 & 3.4 & 4.6 & 0.50 \\
\hline Coffee & 6503 & 13 & 0.29 & 0.63 & 76 & 2.5 & 2.9 & 3.4 & . & 0.82 \\
\hline Refrigerator & 14009 & 11 & 0.29 & 0.05 & 63 & 3.3 & 2.9 & 3.4 & . & 0.65 \\
\hline Sardines & 121 & 6 & 0.29 & 0.09 & 35 & 2.8 & 2.6 & 3.5 & & 0.52 \\
\hline Flour & 516 & 12 & 0.29 & 0.33 & 68 & 2.5 & 1.9 & 3.5 & . & 1.10 \\
\hline Floor cleaner & 11003 & 3 & 0.29 & 0.06 & 17 & 2.7 & 2.1 & 3.5 & . & 1.07 \\
\hline Refrigerator & 14011 & 12 & 0.29 & 0.04 & 68 & 3.0 & 2.6 & 3.5 &. & 0.54 \\
\hline Soap & 10022 & 28 & 0.29 & 0.09 & 160 & 2.6 & 2.8 & 3.5 & 4.1 & 0.20 \\
\hline Baby food & 129 & 10 & 0.29 & 0.24 & 57 & 3.0 & 2.3 & 3.5 &. & 1.02 \\
\hline Sauce mix & 6710 & 5 & 0.29 & 0.43 & 28 & 3.2 & 2.1 & 3.5 & . & 1.10 \\
\hline Canned food & 126 & 2 & 0.28 & 0.92 & 11 & 3.6 & 4.6 & 3.5 & . & 0.52 \\
\hline $\begin{array}{l}\text { Apple sauce, canned, } \\
\text { Israeli }\end{array}$ & 132 & 2 & 0.28 & 0.06 & 11 & 3.0 & 3.0 & 3.5 & . & 0.38 \\
\hline Pork chops & 2501 & 4 & 0.28 & 0.28 & 22 & 2.9 & 2.1 & 3.5 & . & 1.17 \\
\hline Pork steak & 2502 & 4 & 0.28 & 0.21 & 22 & 2.4 & 1.8 & 3.5 & . & 1.20 \\
\hline Tuna, frozen & 4010 & 2 & 0.28 & 0.10 & 11 & 2.6 & 2.8 & 3.5 & . & -0.13 \\
\hline Red sweet wine, Israeli & 6002 & 8 & 0.28 & 0.42 & 44 & 2.7 & 2.1 & 3.5 & . & 0.91 \\
\hline Video recorder & 14018 & 4 & 0.28 & 0.12 & 22 & 2.2 & 2.6 & 3.5 & . & 0.39 \\
\hline Soap, medicated, acne & 24021 & 2 & 0.28 & 1.35 & 11 & 3.2 & 1.5 & 3.5 & . & 0.54 \\
\hline oil & 5002 & 7 & 0.28 & 0.32 & 38 & 2.2 & 2.1 & 3.6 & . & 0.42 \\
\hline Food processor & 14016 & 7 & 0.28 & 0.36 & 38 & 3.4 & 2.7 & 3.6 & . & 1.23 \\
\hline Frozen dough & 2005 & 5 & 0.28 & 0.10 & 27 & 2.9 & 2.9 & 3.6 & . & 0.48 \\
\hline Beer, black & 6017 & 5 & 0.28 & 0.22 & 27 & 2.3 & 1.9 & 3.6 & & 1.31 \\
\hline Eggs & 5005 & 8 & 0.28 & 1.17 & 43 & 3.0 & 1.9 & 3.6 & & 1.36 \\
\hline Diet bread & 511 & 3 & 0.28 & 0.25 & 16 & 2.9 & 3.2 & 3.6 & & 0.97 \\
\hline Whipped topping & 526 & 9 & 0.28 & 0.12 & 49 & 2.4 & 1.8 & 3.6 & 4.5 & 0.61 \\
\hline Dish cleaner, non-liquid & 10001 & 18 & 0.28 & 0.29 & 96 & 3.3 & 3.5 & 3.6 & 4.9 & 0.55 \\
\hline Waffles & 5501 & 5 & 0.27 & 0.03 & 26 & 2.0 & 2.1 & 3.7 &. & 0.65 \\
\hline Oven & 14001 & 5 & 0.27 & 0.33 & 26 & 2.4 & 2.4 & 3.7 & . & 1.16 \\
\hline Cocoa & 6501 & 13 & 0.27 & 0.08 & 67 & 3.6 & 2.5 & 3.7 &. & 0.96 \\
\hline Plastic tablecloths & 10018 & 13 & 0.27 & 0.44 & 70 & 2.0 & 1.5 & 3.7 & 5.0 & 0.82 \\
\hline Beef steak & 1503 & 11 & 0.26 & 0.27 & 56 & 2.2 & 2.2 & 3.8 & 4.9 & 0.49 \\
\hline Whole wheat bread & 519 & 4 & 0.26 & 0.07 & 20 & 2.9 & 1.8 & 3.8 & & 0.65 \\
\hline Pastrami, smoked turkey & 3506 & 5 & 0.26 & 0.95 & 25 & 2.8 & 2.6 & 3.8 & . & 0.41 \\
\hline Mayonnaise & 5010 & 13 & 0.26 & 0.25 & 65 & 3.2 & 3.4 & 3.8 & 4.8 & 0.40 \\
\hline Wine, white dry & 6005 & 5 & 0.26 & 0.56 & 25 & 2.8 & 2.1 & 3.8 & & 0.82 \\
\hline Skin cream, antibiotic & 24005 & 2 & 0.26 & 0.15 & 10 & 3.2 & 1.2 & 3.8 & . & 0.49 \\
\hline Solution for contact lenses & 24026 & 2 & 0.26 & 0.09 & 10 & 3.6 & 4.6 & 3.8 & . & 0.40 \\
\hline Moisturizer & 32504 & 5 & 0.26 & 0.39 & 25 & 2.8 & 1.7 & 3.8 & . & 1.22 \\
\hline Chopped chicken/turkey & 3010 & 14 & 0.26 & 0.43 & 69 & 2.4 & 2.3 & 3.9 & . & 0.24 \\
\hline Decaffeinated coffee & 6509 & 8 & 0.26 & 0.55 & 39 & 3.7 & 2.3 & 3.9 & . & 0.81 \\
\hline Dishwasher & 14019 & 7 & 0.25 & 0.41 & 34 & 3.2 & 3.0 & 3.9 & . & 0.94 \\
\hline Beef, ribs & 1508 & 13 & 0.25 & 0.15 & 63 & 2.8 & 2.3 & 3.9 & . & 1.36 \\
\hline Franks & 3509 & 5 & 0.25 & 0.27 & 24 & 3.3 & 3.1 & 4.0 & & 0.75 \\
\hline Champagne & 6008 & 5 & 0.25 & 0.05 & 24 & 3.6 & 2.7 & 4.0 & & 0.87 \\
\hline
\end{tabular}




\begin{tabular}{|c|c|c|c|c|c|c|c|c|c|c|}
\hline Liquor & 6013 & 5 & 0.25 & 0.17 & 24 & 2.7 & 2.0 & 4.0 & & 0.15 \\
\hline Baking soda & 111 & 8 & 0.25 & 0.02 & 38 & 2.7 & 1.9 & 4.0 & & 1.55 \\
\hline Black olives, canned & 112 & 4 & 0.25 & 0.11 & 19 & 2.3 & 1.8 & 4.0 & & 0.64 \\
\hline Waffles & 5503 & 4 & 0.25 & 0.07 & 19 & 3.2 & 2.9 & 4.0 & & 0.52 \\
\hline Electric mixer, imported & 14015 & 4 & 0.25 & 0.05 & 19 & 4.1 & 2.7 & 4.0 & & 0.98 \\
\hline Beef & 1507 & 19 & 0.25 & 0.20 & 91 & 3.2 & 2.6 & 4.0 & 7.1 & 1.29 \\
\hline Baby food & 130 & 6 & 0.25 & 0.38 & 28 & 3.3 & 2.0 & 4.1 & 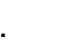 & 1.09 \\
\hline Humus, canned & 5013 & 6 & 0.25 & 0.36 & 28 & 3.5 & 2.5 & 4.1 & & 1.08 \\
\hline Detergent, hand wash & 10011 & 12 & 0.25 & 0.09 & 56 & 3.4 & 2.0 & 4.1 & 6.1 & 0.79 \\
\hline Baby care book & 25508 & 3 & 0.25 & 0.15 & 14 & 2.6 & 2.1 & 4.1 & 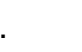 & 1.28 \\
\hline Body lotion & 32507 & 3 & 0.25 & 0.15 & 14 & 3.8 & 2.2 & 4.1 & . & 1.39 \\
\hline Wooden chair & 12004 & 5 & 0.24 & 0.42 & 23 & 3.2 & 2.5 & 4.1 & . & 1.34 \\
\hline Pliers & 11006 & 2 & 0.24 & 0.77 & 9 & 2.0 & 1.3 & 4.2 & . & 0.00 \\
\hline Desk & 12015 & 6 & 0.24 & 0.42 & 27 & 3.5 & 2.1 & 4.2 & . & 1.06 \\
\hline Cognac Franks & 3508 & 5 & 0.23 & 0.65 & 22 & 2.7 & 2.2 & 4.3 & . & 0.62 \\
\hline Beef & 1509 & 13 & 0.23 & 0.23 & 58 & 3.3 & 3.0 & 4.3 & . & 1.31 \\
\hline Jam, Imported & 104 & 8 & 0.23 & 0.39 & 35 & 3.7 & 3.0 & 4.3 & . & 0.60 \\
\hline Metal scrubber pad & 10003 & 11 & 0.23 & 0.75 & 48 & 3.4 & 3.3 & 4.3 & . & 1.14 \\
\hline Frozen egg rolls & 2009 & 4 & 0.23 & 0.04 & 17 & 3.0 & 2.1 & 4.4 & . & 0.61 \\
\hline Tehina mix & 6709 & 4 & 0.23 & 0.18 & 17 & 3.1 & 1.8 & 4.4 & . & 1.01 \\
\hline Cookbook & 25504 & 4 & 0.23 & 0.11 & 17 & 3.6 & 2.6 & 4.4 & . & 0.79 \\
\hline Candy & 5516 & 8 & 0.22 & 0.02 & 33 & 2.9 & 1.9 & 4.5 & . & 0.73 \\
\hline Garden peas, canned & 124 & 7 & 0.22 & 0.16 & 29 & 2.4 & 2.3 & 4.6 & . & 0.60 \\
\hline Lamb & 1506 & 6 & 0.22 & 0.33 & 25 & 3.0 & 2.0 & 4.6 & . & 1.08 \\
\hline Frozen Bourikas & 2008 & 1 & 0.22 & & 4 & 4.5 & 3.6 & 4.6 & . & 1.17 \\
\hline Salami & 3511 & 4 & 0.22 & 0.66 & 16 & 4.3 & 3.2 & 4.6 & . & 0.31 \\
\hline Shampoo & 32502 & 4 & 0.22 & 0.45 & 16 & 3.4 & 3.6 & 4.6 & . & 0.94 \\
\hline Toothbrush & 32521 & 3 & 0.22 & 0.05 & 12 & 4.3 & 4.3 & 4.6 & . & 1.45 \\
\hline Deodorant & 32522 & 3 & 0.22 & 0.33 & 12 & 4.7 & 3.4 & 4.6 & . & 1.06 \\
\hline Marriage band, gold & 33001 & 1 & 0.22 & & 4 & 5.0 & 4.7 & 4.6 & . & 0.21 \\
\hline Necklace, gold & 33002 & 2 & 0.22 & 0.92 & 8 & 4.8 & 4.7 & 4.6 & . & 0.67 \\
\hline Beef & 1510 & 14 & 0.21 & 0.17 & 56 & 3.0 & 2.5 & 4.7 & . & 1.38 \\
\hline Garbage bags & 10016 & 14 & 0.21 & 0.40 & 53 & 3.2 & 3.7 & 4.8 & . & 0.33 \\
\hline Rag for floor & 10015 & 12 & 0.21 & 0.23 & 47 & 2.8 & 2.7 & 4.8 & . & 0.68 \\
\hline Mushrooms, canned & 127 & 7 & 0.20 & 0.31 & 26 & 2.3 & 1.7 & 4.9 & . & -0.01 \\
\hline Beans & 520 & 10 & 0.20 & 0.17 & 39 & 2.5 & 1.9 & 4.9 & 6.0 & -0.02 \\
\hline Salami & 2504 & 3 & 0.20 & 0.10 & 11 & 4.5 & 1.7 & 4.9 & . & 1.08 \\
\hline Walnuts & 9506 & 3 & 0.20 & 0.16 & 11 & 3.4 & 2.4 & 4.9 & . & 0.87 \\
\hline Salami & 3501 & 5 & 0.20 & 0.91 & 18 & 3.9 & 3.5 & 5.0 & . & 0.61 \\
\hline White flour & 515 & 14 & 0.20 & 0.07 & 50 & 3.2 & 2.4 & 5.0 & . & 0.75 \\
\hline Beef & 1513 & 8 & 0.20 & 0.34 & 28 & 3.3 & 2.2 & 5.1 & . & 1.08 \\
\hline Eggs & 5004 & 6 & 0.20 & 1.36 & 21 & 4.0 & 2.8 & 5.1 & . & 0.81 \\
\hline Herbal tea bags & 6508 & 6 & 0.20 & 0.04 & 21 & 4.7 & 4.5 & 5.1 & . & 0.96 \\
\hline Pendant, gold & 33003 & 2 & 0.20 & 1.03 & 7 & 5.6 & 6.1 & 5.1 & . & 1.08 \\
\hline Bracelet, gold & 33004 & 2 & 0.20 & 0.16 & 7 & 5.9 & 6.0 & 5.1 & . & 1.10 \\
\hline Hallah bread & 507 & 7 & 0.19 & 0.01 & 24 & 4.8 & 2.7 & 5.2 & . & 1.12 \\
\hline Book shelves & 12009 & 7 & 0.19 & 0.50 & 24 & 4.7 & 3.4 & 5.2 & . & 0.83 \\
\hline Tuna, canned & 122 & 6 & 0.19 & 0.23 & 20 & 4.5 & 3.3 & 5.3 & . & 0.73 \\
\hline White bread & 502 & 9 & 0.19 & 0.01 & 30 & 4.8 & 2.7 & 5.3 & & 0.94 \\
\hline Bread crumbs & 534 & 6 & 0.19 & 0.35 & 20 & 3.5 & 3.0 & 5.3 & & 0.71 \\
\hline Salami & 3503 & 3 & 0.19 & 0.85 & 10 & 3.0 & 2.1 & 5.3 & . & 0.07 \\
\hline Halva, sesame & 5515 & 3 & 0.19 & 0.19 & 10 & 4.3 & 2.4 & 5.3 & & 0.93 \\
\hline Candy & 5522 & 9 & 0.19 & 0.17 & 30 & 3.3 & 2.5 & 5.3 & . & 0.56 \\
\hline Vodka & 6011 & 6 & 0.19 & 0.19 & 20 & 3.9 & 3.0 & 5.3 & . & 0.37 \\
\hline
\end{tabular}




\begin{tabular}{|c|c|c|c|c|c|c|c|c|c|}
\hline Black bread & 501 & 10 & 0.19 & 0.01 & 33 & 5.2 & 2.5 & 5.3 & 0.90 \\
\hline Rice & 522 & 4 & 0.18 & 0.07 & 13 & 3.1 & 3.7 & 5.4 & 0.30 \\
\hline Popcorn & 538 & 4 & 0.18 & 0.30 & 13 & 4.7 & 3.5 & 5.4 & 2.25 \\
\hline Almonds & 9507 & 4 & 0.18 & 0.10 & 13 & 4.1 & 4.5 & 5.4 & 1.05 \\
\hline Birdcage & 29510 & 4 & 0.18 & 0.13 & 12 & 2.5 & 2.2 & 5.4 & 1.08 \\
\hline Mint or hard candies & 5518 & 9 & 0.18 & 0.50 & 29 & 3.6 & 2.3 & 5.4 & 0.82 \\
\hline Closet & 12001 & 5 & 0.18 & 0.47 & 17 & 4.1 & 3.1 & 5.5 & 0.70 \\
\hline Rolls & 509 & 6 & 0.18 & 0.11 & 19 & 4.9 & 3.7 & 5.5 & 0.66 \\
\hline Tea, packaged & 6506 & 7 & 0.18 & 0.35 & 22 & 5.0 & 3.7 & 5.6 & 0.84 \\
\hline Lentils & 5517 & 10 & 0.18 & 0.07 & 31 & 3.5 & 1.7 & 5.6 & 0.73 \\
\hline Salami & 2505 & 3 & 0.17 & 0.08 & 9 & 5.3 & 4.0 & 5.8 & 1.21 \\
\hline Stuffed vegetables & 7003 & 3 & 0.17 & 0.51 & 9 & 2.8 & 2.3 & 5.8 & 0.43 \\
\hline Wooden table & 12003 & 6 & 0.17 & 0.62 & 18 & 4.3 & 3.1 & 5.8 & 1.15 \\
\hline Vacuum cleaner & 14014 & 2 & 0.17 & 0.11 & 6 & 5.7 & 3.1 & 5.8 & 1.76 \\
\hline Electric kettle & 14509 & 2 & 0.17 & 0.69 & 6 & 4.5 & 2.6 & 5.8 & 1.15 \\
\hline Bible & 25022 & 1 & 0.17 & & 3 & 5.0 & 1.4 & 5.8 & 1.31 \\
\hline Lipstick & 32509 & 2 & 0.17 & 1.26 & 6 & 6.3 & 3.2 & 5.8 & 1.61 \\
\hline Gold bracelet & 33005 & 1 & 0.17 & & 3 & 7.0 & 7.1 & 5.8 & 2.14 \\
\hline Sugar & 6701 & 15 & 0.17 & 0.08 & 46 & 3.3 & 3.6 & 5.8 & 0.15 \\
\hline Chocolate spread & 5514 & 10 & 0.17 & 0.16 & 29 & 3.3 & 2.9 & 5.9 & 0.37 \\
\hline Pita bread & 510 & 9 & 0.17 & 0.91 & 27 & 3.6 & 2.5 & 5.9 & 0.68 \\
\hline Fish & 7007 & 8 & 0.17 & 0.60 & 22 & 5.1 & 4.8 & 5.9 & 0.95 \\
\hline Beef, liver & 1512 & 6 & 0.17 & 0.10 & 17 & 4.1 & 2.7 & 6.0 & 1.06 \\
\hline Salad & 5007 & 6 & 0.17 & 0.55 & 17 & 4.1 & 3.6 & 6.0 & 0.79 \\
\hline Youth bed & 12018 & 5 & 0.17 & 0.45 & 14 & 3.9 & 2.1 & 6.1 & 0.66 \\
\hline Beef, rib & 1501 & 16 & 0.16 & 0.07 & 44 & 4.1 & 5.3 & 6.1 & 0.65 \\
\hline $\begin{array}{l}\text { Textbook on Israeli } \\
\text { literature }\end{array}$ & 25001 & 4 & 0.16 & 0.01 & 11 & 5.2 & 5.0 & 6.1 & 1.10 \\
\hline Flour & 535 & 6 & 0.16 & 0.05 & 16 & 2.9 & 2.5 & 6.3 & 0.60 \\
\hline Ham & 2506 & 3 & 0.16 & 0.22 & 8 & 4.1 & 2.0 & 6.3 & 1.00 \\
\hline Tea & 6507 & 9 & 0.16 & 0.68 & 24 & 3.5 & 2.8 & 6.3 & 0.58 \\
\hline Sandwich & 7502 & 3 & 0.16 & 0.71 & 8 & 4.9 & 2.0 & 6.3 & 1.56 \\
\hline Living room set & 12006 & 3 & 0.16 & 0.65 & 8 & 3.1 & 1.8 & 6.3 & 0.79 \\
\hline Mattress & 12501 & 3 & 0.16 & 0.51 & 8 & 3.6 & 2.5 & 6.3 & 0.88 \\
\hline Beef, chopped & 1511 & 15 & 0.15 & 0.36 & 39 & 3.7 & 3.6 & 6.5 & 0.86 \\
\hline Fish, canned & 123 & 2 & 0.15 & 0.30 & 5 & 3.8 & 3.4 & 6.6 & 0.51 \\
\hline Black bread & 503 & 4 & 0.15 & 0.41 & 10 & 4.1 & 3.1 & 6.6 & 0.65 \\
\hline Tea & 7509 & 2 & 0.15 & 0.69 & 5 & 4.4 & 1.7 & 6.6 & 0.96 \\
\hline Plants of Israel (book) & 25023 & 4 & 0.15 & 0.04 & 10 & 4.8 & 3.2 & 6.6 & 1.03 \\
\hline Color picture & 28501 & 6 & 0.15 & 0.12 & 15 & 5.6 & 4.3 & 6.6 & 1.22 \\
\hline Film, $35 \mathrm{~mm}$ camera & 28502 & 6 & 0.15 & 0.13 & 15 & 6.1 & 4.9 & 6.6 & 1.02 \\
\hline Rice & 521 & 7 & 0.15 & 0.15 & 17 & 4.1 & 3.4 & 6.7 & 0.73 \\
\hline Syrup & 5519 & 5 & 0.15 & 0.04 & 12 & 6.7 & 4.0 & 6.8 & 1.12 \\
\hline Green olives & 114 & 6 & 0.14 & 0.30 & 15 & 4.3 & 3.7 & 6.9 & 0.73 \\
\hline Cocktail franks & 3510 & 3 & 0.14 & 0.33 & 7 & 3.6 & 2.4 & 6.9 & 0.34 \\
\hline Hammer & 11005 & 3 & 0.14 & 0.39 & 7 & 2.3 & 2.0 & 6.9 & 0.30 \\
\hline Screwdriver & 11009 & 3 & 0.14 & 0.24 & 7 & 1.9 & 1.0 & 6.9 & -0.37 \\
\hline Twin bed & 12016 & 3 & 0.14 & 0.49 & 7 & 7.1 & 4.1 & 6.9 & 1.02 \\
\hline Reader, E.M.T. & 25014 & 3 & 0.14 & 0.05 & 7 & 6.0 & 4.8 & 6.9 & 1.23 \\
\hline After shave lotion & 32516 & 3 & 0.14 & 0.43 & 7 & 6.0 & 2.4 & 6.9 & 1.46 \\
\hline Beef, roast & 1502 & 20 & 0.14 & 0.10 & 46 & 4.3 & 4.8 & 7.0 & 0.60 \\
\hline Pliers & 11007 & 4 & 0.14 & 0.26 & 9 & 3.9 & 2.9 & 7.1 & -1.12 \\
\hline Textbook & 25006 & 4 & 0.14 & 0.14 & 9 & 7.2 & 5.5 & 7.1 & 0.88 \\
\hline Geography book & 25016 & 4 & 0.14 & 0.03 & 9 & 6.1 & 4.5 & 7.1 & 0.81 \\
\hline Shaving cream & 32517 & 4 & 0.14 & 0.22 & 9 & 3.7 & 2.3 & 7.1 & 1.12 \\
\hline
\end{tabular}




\begin{tabular}{|c|c|c|c|c|c|c|c|c|c|}
\hline Margarine & 4521 & 18 & 0.14 & 0.01 & 40 & 3.4 & 2.0 & 7.1 & 0.73 \\
\hline Cheese triangles & 4511 & 18 & 0.14 & 0.01 & 39 & 5.5 & 3.5 & 7.3 & 0.58 \\
\hline Beef & 7004 & 12 & 0.14 & 0.79 & 26 & 5.4 & 3.8 & 7.3 & 0.92 \\
\hline Film, 35 mm camera & 28503 & 7 & 0.14 & 0.12 & 16 & 4.9 & 4.9 & 7.3 & 0.86 \\
\hline Wax, car & 32008 & 9 & 0.14 & 0.12 & 20 & 4.7 & 4.3 & 7.4 & 0.66 \\
\hline Pickles & 116 & 6 & 0.13 & 0.12 & 12 & 3.6 & 2.7 & 7.7 & 0.53 \\
\hline White bread & 504 & 3 & 0.13 & 0.11 & 6 & 6.2 & 4.5 & 7.7 & 0.80 \\
\hline Hallah bread & 506 & 2 & 0.13 & 0.41 & 4 & 4.0 & 1.9 & 7.7 & 0.53 \\
\hline Matza bread & 512 & 2 & 0.13 & 0.10 & 4 & 2.5 & 1.7 & 7.7 & 1.09 \\
\hline Franks & 2503 & 3 & 0.13 & 1.37 & 6 & 5.5 & 2.2 & 7.7 & 0.17 \\
\hline Yellow Cheese & 4517 & 4 & 0.13 & 0.08 & 8 & 5.3 & 2.5 & 7.7 & 0.73 \\
\hline Table salt & 6703 & 14 & 0.13 & 0.07 & 28 & 6.4 & 3.0 & 7.7 & 0.94 \\
\hline Coffee & 7510 & 2 & 0.13 & 0.66 & 4 & 3.8 & 2.2 & 7.7 & 0.96 \\
\hline Raisins & 9508 & 4 & 0.13 & 0.33 & 8 & 5.0 & 2.8 & 7.7 & 0.55 \\
\hline Nails & 11011 & 3 & 0.13 & 0.72 & 6 & 4.7 & 2.8 & 7.7 & -0.20 \\
\hline Wooden table & 12007 & 5 & 0.13 & 0.84 & 10 & 5.8 & 3.7 & 7.7 & 1.29 \\
\hline Pot & 15513 & 2 & 0.13 & 0.08 & 4 & 5.5 & 3.0 & 7.7 & 1.62 \\
\hline Language book & 25002 & 2 & 0.13 & 0.09 & 4 & 4.8 & 4.1 & 7.7 & 0.70 \\
\hline History Lessons & 25004 & 5 & 0.13 & 0.16 & 10 & 5.7 & 4.5 & 7.7 & 0.99 \\
\hline History book & 25005 & 3 & 0.13 & 0.17 & 6 & 7.2 & 5.0 & 7.7 & 1.58 \\
\hline Geometry book & 25007 & 4 & 0.13 & 0.03 & 8 & 5.9 & 4.1 & 7.7 & 0.93 \\
\hline Language book & 25017 & 1 & 0.13 & & 2 & 9.5 & 7.5 & 7.7 & 0.94 \\
\hline Pen & 26007 & 4 & 0.13 & 0.15 & 8 & 7.8 & 5.5 & 7.7 & 1.12 \\
\hline Game & 30004 & 1 & 0.13 & & 2 & 3.5 & 1.5 & 7.7 & 2.04 \\
\hline Car oil & 31003 & 8 & 0.13 & 0.03 & 16 & 7.5 & 5.8 & 7.7 & 0.73 \\
\hline Car mirror & 32006 & 7 & 0.13 & 0.20 & 15 & 3.8 & 2.9 & 7.7 & 0.64 \\
\hline Margarine & 4522 & 14 & 0.13 & 0.02 & 27 & 3.4 & 1.6 & 7.9 & 0.57 \\
\hline Flavorings & 528 & 12 & 0.13 & 0.17 & 24 & 4.5 & 2.3 & 7.9 & 0.80 \\
\hline Beef & 1504 & 23 & 0.13 & 0.39 & 44 & 5.5 & 5.8 & 7.9 & 0.67 \\
\hline Long-life milk & 4502 & 16 & 0.13 & 0.02 & 30 & 5.9 & 3.1 & 8.0 & 0.71 \\
\hline Upholstery covers & 32001 & 12 & 0.12 & 0.16 & 21 & 4.9 & 3.3 & 8.1 & 0.77 \\
\hline Television stand & 12012 & 5 & 0.12 & 0.20 & 9 & 3.4 & 2.6 & 8.2 & 0.55 \\
\hline Pudding & 4510 & 14 & 0.12 & 0.10 & 25 & 6.4 & 3.4 & 8.3 & 0.44 \\
\hline Chicken & 7006 & 9 & 0.12 & 0.49 & 16 & 5.9 & 4.5 & 8.3 & 0.73 \\
\hline Baking powder & 527 & 8 & 0.12 & 0.93 & 15 & 5.3 & 2.8 & 8.4 & 0.97 \\
\hline Yellow Cheese & 4516 & 12 & 0.12 & 0.03 & 21 & 6.8 & 3.0 & 8.4 & 0.67 \\
\hline Razor blade & 32518 & 4 & 0.12 & 0.37 & 8 & 7.3 & 5.3 & 8.4 & 0.69 \\
\hline Corn flour & 518 & 3 & 0.12 & 0.51 & 6 & 7.2 & 4.3 & 8.6 & 0.53 \\
\hline Yogurt & 4507 & 6 & 0.12 & 0.02 & 10 & 5.9 & 3.7 & 8.6 & 0.73 \\
\hline Cheese & 4515 & 9 & 0.12 & 0.20 & 15 & 6.1 & 3.5 & 8.6 & 0.56 \\
\hline Lamb & 7005 & 3 & 0.12 & 0.50 & 4 & 6.3 & 3.8 & 8.6 & 0.67 \\
\hline $\begin{array}{l}\text { Alcoholic beverage } \\
\text { (Arrack) }\end{array}$ & 6012 & 5 & 0.11 & 0.18 & 8 & 6.5 & 2.4 & 8.8 & 0.33 \\
\hline Pistachio nuts & 9505 & 5 & 0.11 & 0.60 & 8 & 7.0 & 4.6 & 8.8 & 0.78 \\
\hline History book & 25015 & 5 & 0.11 & 0.07 & 8 & 6.5 & 5.2 & 8.8 & 1.32 \\
\hline Yellow Cheese & 4518 & 16 & 0.11 & 0.01 & 25 & 6.9 & 3.0 & 9.0 & 0.64 \\
\hline Sweet paprika & 6705 & 10 & 0.11 & 0.42 & 18 & 4.2 & 4.3 & 9.2 & 0.47 \\
\hline Dictionary & 25020 & 4 & 0.11 & 0.14 & 6 & 4.2 & 2.2 & 9.2 & 0.36 \\
\hline Song book & 25512 & 4 & 0.11 & 0.21 & 6 & 5.0 & 3.8 & 9.2 & 0.76 \\
\hline Newspaper & 25517 & 2 & 0.11 & 0.02 & 3 & 13.0 & 8.6 & 9.2 & 1.02 \\
\hline Children's game & 30009 & 2 & 0.11 & 0.16 & 3 & 6.0 & 2.9 & 9.2 & 1.30 \\
\hline Chocolate pudding & 4504 & 13 & 0.11 & 0.23 & 19 & 6.7 & 3.2 & 9.3 & 0.72 \\
\hline Matches & 10027 & 26 & 0.11 & 0.06 & 38 & 4.2 & 3.1 & 9.3 & 0.72 \\
\hline Steering wheel cover & 32007 & 14 & 0.11 & 0.16 & 20 & 6.6 & 5.1 & 9.5 & 1.34 \\
\hline Sour cream & 4514 & 12 & 0.11 & 0.07 & 17 & 8.1 & 2.7 & 9.5 & 0.00 \\
\hline
\end{tabular}




\begin{tabular}{|c|c|c|c|c|c|c|c|c|c|}
\hline Candles & 10026 & 18 & 0.10 & 0.19 & 26 & 4.4 & 3.0 & 9.6 & 0.46 \\
\hline Black pepper dispenser & 6704 & 11 & 0.10 & 0.11 & 17 & 3.2 & 3.0 & 9.7 & 0.33 \\
\hline Canned meat & 128 & 6 & 0.10 & 0.52 & 8 & 5.6 & 3.3 & 9.9 & 0.94 \\
\hline Bourikas & 1011 & 3 & 0.10 & 0.44 & 3 & 3.0 & 1.6 & 9.9 & 0.66 \\
\hline Cheese & 4520 & 6 & 0.10 & 0.36 & 8 & 4.6 & 3.4 & 9.9 & 0.60 \\
\hline Kitchen table & 12014 & 3 & 0.10 & 0.24 & 5 & 6.6 & 4.2 & 9.9 & 1.15 \\
\hline Night tables & 12017 & 3 & 0.10 & 0.56 & 5 & 4.0 & 2.1 & 9.9 & 0.46 \\
\hline Tape recorder & 14017 & 3 & 0.10 & 0.30 & 5 & 2.6 & 2.2 & 9.9 & 0.12 \\
\hline Language book & 25003 & 3 & 0.10 & 0.08 & 5 & 3.6 & 3.3 & 9.9 & 0.42 \\
\hline Language book & 25013 & 3 & 0.10 & 0.02 & 4 & 8.0 & 4.1 & 9.9 & 0.92 \\
\hline Geography book & 25018 & 3 & 0.10 & 0.28 & 4 & 9.3 & 4.5 & 9.9 & 0.80 \\
\hline Dictionary & 25019 & 3 & 0.10 & 0.08 & 4 & 8.8 & 3.6 & 9.9 & 1.14 \\
\hline Milk & 4501 & 19 & 0.10 & 0.00 & 24 & 7.8 & 2.8 & 10.2 & 0.56 \\
\hline White cheese & 4512 & 8 & 0.10 & 0.09 & 10 & 7.6 & 2.9 & 10.2 & 0.69 \\
\hline Dessert & 7008 & 4 & 0.10 & 0.57 & 5 & 7.8 & 5.6 & 10.2 & 1.00 \\
\hline Cottage cheese & 4513 & 17 & 0.10 & 0.01 & 21 & 8.0 & 2.9 & 10.3 & 0.58 \\
\hline Salted cheese & 4519 & 9 & 0.10 & 0.45 & 11 & 7.7 & 2.8 & 10.4 & 0.62 \\
\hline Notebook & 26002 & 5 & 0.10 & 0.13 & 5 & 3.4 & 3.2 & 10.5 & 0.45 \\
\hline Film for camera & 28505 & 5 & 0.10 & 0.16 & 7 & 5.1 & 5.4 & 10.5 & 0.87 \\
\hline Car carpet & 32005 & 10 & 0.10 & 0.17 & 14 & 5.6 & 4.6 & 10.5 & 0.54 \\
\hline Journal & 25519 & 6 & 0.09 & 0.00 & 7 & 7.6 & 7.3 & 10.6 & 0.32 \\
\hline Entr e & 7001 & 11 & 0.09 & 0.48 & 14 & 5.6 & 3.2 & 11.0 & 0.87 \\
\hline Cleaner & 32009 & 11 & 0.09 & 0.16 & 14 & 4.7 & 3.2 & 11.0 & 0.99 \\
\hline Matzo meal & 517 & 2 & 0.09 & 0.59 & 2 & 9.5 & 4.5 & 11.5 & 1.79 \\
\hline Fish & 4003 & 1 & 0.09 & & & & & 11.5 & 0.00 \\
\hline Drink & 7507 & 3 & 0.09 & 0.58 & 4 & 3.5 & 1.7 & 11.5 & 0.61 \\
\hline Peanuts & 9503 & 4 & 0.09 & 0.14 & 4 & 8.8 & 4.8 & 11.5 & 0.80 \\
\hline Wooden chair & 12005 & 5 & 0.09 & 0.31 & 6 & 6.2 & 5.5 & 11.5 & 0.65 \\
\hline Couch & 12019 & 2 & 0.09 & 1.29 & 2 & 9.5 & 7.5 & 11.5 & 0.74 \\
\hline Plastic lenses & 24504 & 3 & 0.09 & 0.21 & 2 & 8.0 & 7.0 & 11.5 & 1.47 \\
\hline Physics book & 25008 & 3 & 0.09 & 0.05 & 3 & 5.7 & 3.1 & 11.5 & 0.76 \\
\hline Paper & 26004 & 5 & 0.09 & 0.37 & 7 & 4.6 & 3.2 & 11.5 & 0.17 \\
\hline Cassette tape & 28007 & 3 & 0.09 & 0.19 & 2 & 11.0 & 9.0 & 11.5 & 0.57 \\
\hline Soap & 32512 & 3 & 0.09 & 0.30 & 4 & 7.5 & 5.9 & 11.5 & 0.41 \\
\hline Wrist watch strap & 33011 & 3 & 0.09 & 0.31 & 2 & 10.5 & 4.5 & 11.5 & 0.66 \\
\hline Chocolate drink & 4503 & 15 & 0.08 & 0.37 & 14 & 4.9 & 3.3 & 11.9 & 0.46 \\
\hline Butter & 4524 & 16 & 0.08 & 0.01 & 13 & 5.5 & 3.2 & 13.1 & 0.26 \\
\hline Soup & 7002 & 8 & 0.08 & 0.24 & 8 & 7.8 & 3.0 & 13.1 & 0.74 \\
\hline Nails & 11012 & 4 & 0.08 & 0.30 & 4 & 7.0 & 3.5 & 13.1 & -1.02 \\
\hline Roll & 508 & 6 & 0.07 & 0.01 & 4 & 6.5 & 3.8 & 13.8 & 0.62 \\
\hline Tweezers & 32520 & 3 & 0.07 & 0.28 & 3 & 6.3 & 3.3 & 13.8 & 0.76 \\
\hline Pen & 26006 & 5 & 0.07 & 0.13 & 5 & 7.4 & 5.3 & 14.4 & 0.99 \\
\hline Markers & 26009 & 5 & 0.07 & 0.33 & 4 & 2.8 & 1.3 & 14.4 & 0.94 \\
\hline Crayons & 26016 & 5 & 0.07 & 0.49 & 4 & 11.5 & 4.2 & 14.4 & 1.02 \\
\hline Car wash & 31005 & 5 & 0.07 & 0.10 & 3 & 13.7 & 5.4 & 14.4 & 1.09 \\
\hline Butter & 4523 & 18 & 0.07 & 0.01 & 9 & 6.2 & 3.6 & 15.3 & 0.26 \\
\hline Spices & 6706 & 10 & 0.07 & 0.32 & 9 & 3.9 & 2.3 & 15.3 & 0.05 \\
\hline Sunflower seeds & 9501 & 4 & 0.07 & 0.17 & 3 & 13.0 & 4.9 & 15.3 & 0.56 \\
\hline Youth bed & 12020 & 2 & 0.07 & 0.23 & 2 & 4.5 & 0.5 & 15.3 & 0.41 \\
\hline Paints & 26010 & 4 & 0.07 & 0.19 & 2 & 10.0 & 5.0 & 15.3 & -0.16 \\
\hline Notebook & 26003 & 5 & 0.06 & 0.36 & 3 & 5.3 & 1.2 & 16.4 & 0.12 \\
\hline Cellophane tape & 26017 & 5 & 0.06 & 0.34 & 2 & 3.5 & 2.5 & 16.4 & 0.76 \\
\hline Glass lenses & 24501 & 3 & 0.06 & 0.18 & & & & & 1.48 \\
\hline Time magazine & 25516 & 4 & 0.05 & 0.00 & & & & & 0.88 \\
\hline
\end{tabular}




\begin{tabular}{|c|c|c|c|c|c|c|c|c|c|}
\hline Speakers & 32004 & 4 & 0.05 & 0.70 & 3 & 12.0 & 4.9 & 18.4 & 0.73 \\
\hline Batteries & 14506 & 3 & 0.04 & 0.20 & & & & & 0.17 \\
\hline Tennis balls & 29004 & 4 & 0.04 & 0.40 & & & & & 0.11 \\
\hline Pencil & 26015 & 6 & 0.04 & 0.12 & 2 & 6.5 & 5.5 & 27.6 & 0.59 \\
\hline Haircut, men's & 33501 & 6 & 0.04 & 0.43 & & & & & 0.60 \\
\hline Whipped topping & 4525 & 13 & 0.03 & 0.14 & 4 & 7.3 & 3.6 & 29.9 & 0.15 \\
\hline Glue & 26014 & 4 & 0.03 & 0.55 & & & & & 0.20 \\
\hline Brush & 26013 & 3 & 0.03 & 0.20 & & & & & 0.91 \\
\hline Haircut, children's & 33503 & 5 & 0.03 & 0.30 & & & & & 0.44 \\
\hline Ruler, $30 \mathrm{~cm}$ & 26008 & 5 & 0.01 & 0.15 & & & & & -0.12 \\
\hline
\end{tabular}


Table 2*: Predicting the length of the period;

Dependent variable $=\Delta t$

\begin{tabular}{llcccc}
\hline $\mathrm{N}$ & $\Delta \mathrm{p}$ & $\begin{array}{c}\text { av. } \Delta \mathrm{p} \\
\text { for prod. }\end{array}$ & $\begin{array}{c}\text { av. } \Delta \mathrm{p} \\
\text { for store }\end{array}$ & $\begin{array}{c}\text { av. inflation } \\
\text { for prod. }\end{array}$ & $\begin{array}{c}\mathrm{SD}(\ln ) \\
\text { for prod. }\end{array}$ \\
13770 & -0.3 & 22.9 & & & \\
& $(-1.7)$ & $(21.3)$ & 27.3 & & \\
13770 & & & & & \\
& & & & 10.25 & 0.45 \\
13770 & -0.3 & 37.0 & & $(1.96)$ & $(3.77)$ \\
& $(-1.5)$ & $(28.9)$ & 25.2 & -118.9 & 0.06 \\
& & & $(21.0)$ & $(-19.8)$ & $(0.5)$
\end{tabular}

Regression based on half of the observations with the least frequent changes (low $\mathrm{E}_{\mathrm{t}}\left(\mathrm{x}_{\mathrm{i}}\right)$ )

$\begin{array}{cccccc}6885 & -0.21 & 13.7 & 24.8 & & \\ & (-0.6) & (8.5) & (14.3) & & \\ & & & & \\ 6885 & & & & 14.53 & -0.84 \\ & & & & (1.38) & (-4.93) \\ 6885 & -0.17 & 24.8 & 23.3 & -118.3 & -0.62 \\ & (-0.5) & (12.5) & (13.5) & (-9.2) & (-3.8)\end{array}$

Regression based on half of the observations with the most frequent changes (high $\mathrm{E}_{\mathrm{t}}\left(\mathrm{x}_{\mathrm{i}}\right)$ )

$\begin{array}{rrrr}6885 & -0.27 & 4.37 & 24.7 \\ & (-1.9) & (2.9) & (16.8)\end{array}$

6885

15.12

0.64

(3.88)

(4.61)

6885

$-0.27 \quad 21.4$

24.2

$-46.2$

0.63

$(-1.9)$

(7.5)

(16.5)

$(-6.4)$

(4.6)

\footnotetext{
* This Table reports OLS regression results. $t$ statistics are in parentheses. The dependent variable is the direct observation of the length of the period $(\Delta t)$. The explanatory variables are the size of the jump $(\Delta \mathrm{p})$, the average size of the jump for the product (av. $\Delta \mathrm{p}$ for prod.), the average size of the jump for the store (av. $\Delta$ p for store), the average inflation rate for the product (average over both zero and
} 
non-zero price changes) and the average standard deviation of lnp for the product. All regressions include monthly dummies.

Note that the average size of the jump (for the product or for the store) is the average over all observations of non-zero nominal price changes. The average inflation rate includes observations of zero nominal price changes.

The first three regressions were run for the entire sample of 13,770 direct observations about the length of the period. We then split the sample by the frequency of price changes. Observations for products with low frequency (low $E_{t}\left(x_{i t}\right)$ ) were included in the first half. 
REFERENCES

Bental, Benjamin, and Eden Benjamin. "Money and Inventories in an Economy with Uncertain and Sequential Trade" Journal of Monetary Economics, 37 (1996) 445-459.

"Reserve requirements and output fluctuations" Journal of Monetary Economics, 49 (2002) 1597-1620.

Bils, Mark and Peter J. Klenow "Some Evidence on the Importance of Sticky Prices" Mimeo, June 2002.

Calvo, Guillermo A., "Staggered Prices in a Utility-Maximizing Framework" Journal of Monetary Economics, XII (1983), 383-398.

Carlton, D.W. "The Rigidity of Prices" American Economic Review, 76, $637-658(1986)$.

Cecchetti, S.G., "The Frequency of Price Adjustment - A Study of the Newsstand Prices of Magazines" Journal of Econometrics, 31, 255$274(1986)$.

Chari, V.V., Patrick J. Kehoe and Ellen McGrattan. "Sticky Price Models of the Business Cycle: Can the Contract Multiplier Solve the Persistence Problem?" Econometrica, Vol. 68, No.5 (September $2000), \quad 1151-1179$.

Crucini Mario J. and Mototsugu Shintani "Persistence in Law-of-One-Price Deviations: Evidence from Micro-Data" Department of Economics, Vanderbilt University, W.P.\#02-W22, December 2002.

Dotsey, M., R. G. King and Wolman A.L., "State-Dependent Pricing and the General Equilibrium Dynamics of Money and Output" Quarterly Journal of Economics, May 1999, 655-690.

Eden, B. "The Adjustment of Prices to Monetary Shocks When Trade is Uncertain and Sequential" Journal of Political Economy, Vol. 102, No. 3, pp. 493-509, June 1994.

"Inflation and Price Adjustment: An analysis of Microdata" Review of Economic Dynamics, 4, 607-636, July 2001. Sequential Trade, Money and Uncertainty, to be published by Blackwell in 2004 .

Kashyap, Anil K. "Sticky Prices: New Evidence from Retail Catalogs" Quarterly Journal of Economics, 110, 1995, 245-274. 
Lach, S. "Existence and Persistence of Price Dispersion: An Empirical Analysis" mimeo, March 2002 . and Tsiddon, D. "The Behavior of Prices and Inflation: an Empirical Analysis of Disaggregated Price Data" Journal of Political Economy, Vol.100, No.2, April 1992, 349-89.

Lucas, Robert. E., Jr. and Michael Woodford "Real Effects of Monetary Shocks In an Economy With Sequential Purchases" Preliminary draft, The University of Chicago, April 1994.

Taylor, John B. "Aggregate Dynamics and Staggered Contracts" Journal of Political Economy, 88 (1980), 1 - 23. "Staggered Price and Wage Setting in Macroeconomics" Chapter 15 in Handbook of Macroeconomics, John B. Taylor and Michael Woodford, eds. Elsevier, New York, 1999.

Williamson, Stephen D. "Sequential Markets and the Suboptimality of the Friedman rule" Journal of Monetary Economics; 37 (3), June 1996. Woodford, Michael "Loan Commitments and Optimal Monetary Policy" Journal of Monetary Economics; $37(3)$, June 1996, 573-605. 